\title{
COMMENTS
}

\section{Federal Powers and the Eleventh Amendment: Attorneys' Fees in Private Suits Against the State}

\author{
Ernest A. Nagata†
}

The author examines alternative bases of federal power to award attorneys' fees in private suits against states or state officials. He first analyzes the scope of federal judicial powers under the eleventh amendment and finds the assessment of nonstatutory fee awards against state officials to be constitutionally permissible under limited circumstances. He then discusses the scope of congressional powers under the eleventh amendment and the use of the implied waiver doctrine as a basis for statutory fee shifting against states. As an alternative the author suggests a refined interpretation of the eleventh amendment. In closing, the author discusses the lawmaking competence of the federal judiciary vis-d-vis that of Congress, and the propriety of judicially implied attorneys' fee remedies against the state.

With the increase in private suits against state officials for the protection of individual liberties and, more generally, in the "public interest," the federal judiciary has increasingly been called upon to adjudicate the successful plaintiff's claim for attorneys' fees. This Comment seeks to analyze the extent of the federal judiciary's authority to impose a decree for plaintiffs' attorneys' fees against a state or its officials. There are two major elements to the problem. The first involves the scope of the federal judiciary's remedial powers in a private suit against a state or its officials. More specifically, to what extent can federal courts compel states to take affirmative action, as in the payment of attorneys' fee judgments from state funds. The second element is the more general question of the proper exercise of a federal court's powers to award attorneys' fees to the prevailing litigant.

† B.S. 1967, University of California, Berkeley; Ph.D. 1971, Purdue University; third-year student, Boalt Hall School of Law; Managing Editor, California Law Review.

1. See generally Nussbaum, Attorney's Fees in Public Interest Litigation, 48 N.Y.U.L. REv. 301 (1973). 
The first issue is the more complex and has been much debated. There is a long tradition in American jurisprudence of state immumity to nonconsensual private suit, resulting either from the common law doctrine of sovereign immunity or the eleventh amendment ${ }^{2}$ limitation on the power of federal courts. However, the federal judiciary, desiring to provide a judicial forum for the redress of unlawful state action, responded to state immumity by making state officials amenable to suit under the doctrine of Ex parte Young, ${ }^{3}$ thus providing at least a partial remedy. Yet, once the officer of the state is subject to suit, it is not clear to what extent decrees which require affirmative action by the state are permitted. Because the state proper is sheltered by constitutional immunity to private suit, a court decree against the state official may be prohibited by the eleventh amendment if the decree operates in substance against the state.

Therefore, the threshold question in discussing reimbursement of hitigation costs is whether federal courts have the judicial power to assess costs that will be paid by the state official from state funds. The Supreme Court's latest reexamination of the eleventh amendment jurisdictional limitation in Edelman v. Jordan ${ }^{4}$ suggests a negative answer, and subsequent decisions by the Courts of Appeals in the Third, Fifth and Sixth Circuits, predicated largely on Edelman, have held such fee awards impermissible under the eleventh amendment. ${ }^{5}$ The Second Circuit, on the other hand, citing other language from Edelman, has upheld an award of attorneys' fees against a state official in the person's official capacity. ${ }^{6}$ As the conflicting circuit court decisions indicate, Edelman does not provide a direct answer; as might be expected in a subject so seemingly illogical as sovereign immunity, the history behind Edelman and the eleventh amendment immunity doctrine is replete with doctrinal changes, inconsistencies, and fictions resulting froin competing interests.

Dissatisfaction with the himited judicial power available under $E x$ parte Young has resulted in the emergence of an alternative doctrinal

2. The eleventh amendment reads:

The Judicial power of the United States shall not be construed to extend to any suit in law or equity, commenced or prosecuted against one of the United States by Citizens of another State, or by Citizens or Subjects of any Foreign State.

U.S. CoNST. amend. XI.

Although the amendment by its terms does not limit the judicial power of the United States over suits against a state by citizens of that state, the amendment was interpreted as having this effect in Hans v. Louisiana, 134 U.S. 1 (1890). See notes 5759 infra and accoinpanying text.

3. 209 U.S. 123 (1908).

4. 415 U.S. 651 (1974).

5. See cases cited at note 141 infra.

6. See cases cited at note 142 infra. 
basis for federal power: implied waiver of eleventh amendment immunity based on state conduct within areas subject to congressional control. ${ }^{7}$ This doctrine also raises difficult eleventh amendment questions, and the issues are far from settled. Nonetheless, the implied waiver doctrine provides a potentially significant means of ameliorating the impact of the eleventh amendment. Thus, this Comment explores the development of the doctrine and its possible applicability to fee shifting against states.

Even if the federal judiciary has the power to require affirmative action by the states, including the payment of state funds, the use of this power to award attorneys' fees to a successful litigant may not be appropriate. This is the second problem on which this Comment is focused. The general American rule bars fee shifting in the absence of specific statutory authorization. ${ }^{8}$ However, federal courts have been invested with the equity power, derived from the English Court of Chancery, to award attorneys' fees to the successful litigant ${ }^{9}$ and have used this judicial power to develop limited, but significant exceptions to the general rule. Guided by considerations of public policy, they have awarded attorneys' fees im numerous types of cases falling within the generic category of public interest litigation. ${ }^{10}$ The situations in which this equitable power may be invoked have been identified in three categories: courts may shift the burden of attorneys' fees to a defendant who has engaged in "obdurate behavior;", 11 fees may be awarded from a

7. For a discussion of the implied waiver doctrine, sce text accompanying notes 206-52 infra.

8. Several commentators have urged a major reform of the general rule against fee shifting. See, e.g., Ehrenzweig, Reimbursement of Counsel Fees and the Great Society, 54 CalIr. L. Rev. 792 (1966); Stoebuck, Counsel Fees Included in Costs: A Logical Development, 38 U. CoLo. L. Rev. 202 (1966); Note, Attorney's Fees: Where Shall the Ultimate Burden Lie?, 20 VaND. L. REv. 1216 (1967).

9. Sprague v. Ticonic Nat'l Bank, 307 U.S. 161, 164-66 (1939); Guardian Trust Co. v. Kansas City S.R.R., 28 F.2d 233, 240-46 (8th Cir. 1928), rev'd on olher grounds, 281 U.S. 1 (1929).

10. E.g., Sims v. Amos, 340 F. Supp. 691 (M.D. Ala. 1972), aff'd mem., 409 U.S. 942 (1972) (reapportionment); Brandenburger v. Thompson, 494 F.2d 885 (9th Cir. 1974) (public assistance); Gates v. Collier, 489 F.2d 298 (1973), aff'd, 501 F.2d 1291 (5th Cir. 1974) (prisoners' rights); Stolberg v. Members of Bd. of Trustees for State Colleges of Conn., 474 F.2d 485 (2d Cir. 1973) (free speech); Griffin v. County School Bd. of Prince Edward County, Virginia, 363 F.2d 206 (4th Cir. 1966), cert. denied, 385 U.S. 960 (1966) (school desegregation); La Raza Unida v. Volpe, 57 F.R.D. 94 (N.D. Cal. 1972), appeal dismissed, Civil No. 73-1145 (9th Cir. May 29, 1975) (nonappealable order) (environmental protection and housing assistance).

11. See, e.g., Hall v. Cole, 412 U.S. 1, 5 (1973); Class v. Norton, 505 F.2d 123, 127 (2d Cir. 1974); Stolberg v. Members of the Bd. of Trustees for State Colleges of Conn., 474 F.2d 485, 490 (2d Cir. 1973). The standard is essentially one of "bad faith," either in the conduct of the litigation or the events leading to the litigation. Hall v. Cole, 415 U.S. 1, 15 (1973). The basic rationale for the fee award is punitive, id. at 5, but the assessment may be made primarily for purposes of deterring any reoccurence of misconduct, Class v. Norton, 505 F.2d 123, 127 (2d Cir. 1974) (appeal pending). See 
"common fund"12 which, as a result of plaintiff's efforts, inures to the benefit of others in plaintiff's class; and until recently, the power to award fees could be used offensively when the plaintiff acted as a "private attorney general"13 in effectuating a strong congressional policy. The private attorney general doctrine lost inuch of its legal standing in Alyeska Pipeline Service Co. $v$. The Wilderness Society, ${ }^{14}$ in which the Supreme Court held that it would be inappropriate for the federal

generally Note, Awarding Attorneys Fees to the "Private Attorney General": Judicial Green Light to Private Litigation in the Public Interest, 24 HAST. L.J. 733, 737-39 (1973) [hereinafter cited as Note, Private Attorney General].

12. See, e.g., Sprague v. Ticonic Nat'1 Bank, 307 U.S. 161, 166-67 (1939). In the traditional "common fund" situation the plaintiff's efforts result in a right to monetary recovery for the class. In Sprague this theory was extended to cover a situation in which the plaintiff, although suing only on behalf of herself, established a right of recovery for others similarly situated through the operation of stare decisis. Finally, in Mills v. Electric Auto-Lite Co., 396 U.S. 375 (1970), the Court extended the "common fund" theory to a "common benefit" theory to allow attorneys" fees where a substantial benefit was conferred upon the class but there was no direct pecuniary recovery. Id. at 391-97. See also Hall v. Cole, 412 U.S. 1 (1973). In Brevier v. School Bd., 456 F.2d 943 (4th Cir. 1972), cert. denied, 406 U.S. 933 (1972), a "quasi" common fund theory was adopted where there was no pecuniary payout to the plaintiffs, but the suit resulted in pecuniary benefits in the form of free busing. See id. at 951-52. See generally Dawson, Lawyers and Involuntary Clients: Attorneys Fees from Funds, 87 HARv. L. REv. 1597 (1974).

13. Northcross v. Board of Educ., 412 U.S. 427, 428 (1973); Brandenburger v. Thompson, 494 F.2d 885, 889 (9th Cir. 1974); Lee v. Southern Home Sites Corp., 444 F.2d 143, 148 (5th Cir. 1971); Sims v. Amos, 340 F. Supp. 691, 694 (M.D. Ala. 1972), aff'd mem., 409 U.S. 942 (1972); La Raza Unida v. Volpe, 57 F.R.D. 94, 98-102 (N.D. Cal. 1972), appeal dismissed, Civil No. 73-1145 (9th Cir. May 29, 1975) (nonappealable order). See generally Note, Private Attorney General, supra note 11.

14. 95 S. Ct. 1612 (1975). The litigation was initiated by The Wilderness Society and other environmental groups in an attempt to enjoin the Secretary of Interior from issuing permits required for the trans-Alaska oil pipeline. Subsequent to the granting of a preliminary injunction the State of Alaska and Alyeska were allowed to intervene. The merits of the litigation were decided (against plaintiffs) by congressional legislation, although the Court of Appeals had found violation of the Mineral Leasing Act of 1920, 30 U.S.C. \& 185 (1970). Despite the plaintiffs' ultimate loss, the Court of Appeals assessed attorneys' fees against Alyeska on the theory that plaintiffs had acted as private attorneys general in seeking to vindicate important statutory rights of all citizens. The Wilderness Society v. Morton, 495 F.2d 1026, 1032-36 (D.C. Cir. 1974). The taxing of fees against the United States was denied on the basis of 28 U.S.C. $₹ 2412$, which provides in pertinent part:

Except as otherwise specifically provided by statute, a judgment for costs, as enumerated in section 1920 of this title but not including the fees and expenses of attorneys may be awarded to the prevailing party in any civil action brought by or against the United States or any agency or official of the United

States acting in his official capacity ....

In addition, the assessmeut of attorneys' fees against the State of Alaska was denied by the Court of Appeals on discretionary grounds on the basis that the state had acted in the public interest by voluntarily intervening to present another view to the public interest implications of the issues. $495 \mathrm{~F} .2 \mathrm{~d}$ at $1036 \mathrm{n} .8$. Certiorari was granted to determine whether the assessment against Alyeska was appropriate. 419 U.S. 823 (1974). 
judiciary to reallocate litigation expenses on a basis which requires the courts, without legislative guidance, to determine which statutes are sufficiently important to merit sucli treatment. ${ }^{15}$ The Court, however, did not repudiate the federal judiciary's inherent power to allow attorneys' fees in particular situations when not forbidden by Congress, and therefore left standing the common benefit and obdurate behavior exceptions. ${ }^{16}$ Tluus, althougl the demise of the private attorney general doctrine has foreclosed awards of attorneys' fees in a substantial number of cases falling within the public interest rubric, the two remaining exceptions, especially with an expansion of the common benefit doctrine, ${ }^{17}$ may yet be applicable to a significant number of public interest suits, and it would be logical to expect plaintiffs to argue along those lines.

No matter what category of exception is claimed, courts must inevitably analyze equitable arguments and policy considerations in determining whether nonstatutory fee shifting would be appropriate.

15. $95 \mathrm{~S}$. Ct. at $1616,1625-27$. In the Court's view, the determination of fee shifting policies and the scope of discretion to be given to the federal courts are matters for Congress to decide. Id. at 1624. In deciding that the courts had not been given carte blanche authority to award attorneys' fees, the Court relied heavily on statutory interpretation of sections 1920 and 1923 (a) of Title 28 of the United States Code. Under section 1920, a court may tax certain specified costs, including the docket fees under section 1923(a). Although sections 1920 and 1923 do not specifically prohibit the assessment of other costs or fees against an opposing party, the Court implied such a prohibition into the sections on the basis of a predecessor statute, 10 Stat. 161 (1853), which provided that certain fees "and no other compensation shall be taxed and allowed." See 95 S. Ct. at 1618-20. The Court's result is not inevitable since, as Justice Marshall's dissent points out, the statute has been construed to permit exceptions to the general rule against fee shifting. Id. at 1629, 1633.

16. $95 \mathrm{~S}$. Ct. at 1621-22.

17. The extent to which the conmon benefit doctrine can be extended is somewhat uncertain. Justice Marshall, dissenting in Alyeska, argued that fee shifting should be permissible under a court's equitable powers when

(1) the important right being protected is one actually or necessarily shared by the general public or some class thereof; $(2)$ the plaintiff's pecuniary interest in the outcome, if any, would not normally justify incurring the cost of counsel; and (3) shifting that cost to the defendant would effectively place it on a class that benefits from the litigation.

Id. at 1635. The Court's opinion, lowever, suggests a narrow application of the common benefit doctrine, with a requirement that there be a direct, easily identifiable relationship between the costs shifted to the class benefiting from the hitigation and the benefits received by them. $I d$. at $1625 \mathrm{n} .39$. Clearly such a relationship becones more difficult to find as one moves away from established cases such as shareliolder derivative suits (Mills v. Electric Auto-Lite Co., 396 U.S. 375 (1970)) or a union member's suit against the union (Hall v. Cole, 412 U.S. 1 (1973)) where there is a relationship between the plaintiffs' benefits and the plaintiffs' interests in the corporate or union funds from which costs must be paid. In prisoners' rights cases, for exanple, it would be difficult to maintain that fee shifting is appropriate on the basis that the taxpaying public is the direct beneficiary of the litigation, although fee shifting could easily have been justified under the private attorney general rationale. 
There are persuasive equitable arguments in favor of fee shifting in suits against states. These arguments devolve in part from the presently recognized restrictions on remedies against the state-in particular, the difficulty in obtaining retroactive relief. ${ }^{18}$ The latter obviously is a financial impediment to bringing private lawsuits. On the other hand, a policy of awarding attorneys' fees to the successful plaintiff is likely to encourage suits. ${ }^{19}$ The balancing of such considerations is within the equity tradition of courts, but the use of federal judicial power in the context of suits against states involves more than questions of jurisdictional limitations or a balancing of the equities. In addition to the eleventh amendinent issues already raised, the use of federal judicial action against states involves considerations of constitutional allocations of power between the state and federal governments. Another issuc involves the constitutional allocation of power between the federal judiciary and Congress. Thus, it may not be appropriatc for the federal courts to act without congressional authorization.

Part I of this Comment surveys the development of the immunity doctrine and examines the scope of permissible relief under the eleventh amendment. Part $I I$ examines the decisional law on nonstatutory attorneys' fees against state officials. Part III examines the scope of congressional powers under the eleventh amendinent and the associated doctrine of implied waiver of eleventh anendment immunity. A reinterpretation of the amendment is suggested as an alternative basis for such congressional powers. Part IV examines the policy considerations involved in the judicial creation of remedies in the context of attorneys' fees.

I

SOVEREIGN Immunity, the EleVEnth AMENDMENT, AND THE DOCTRINe OF EX PARTe Young

The continuing validity of the doctrine of sovereign immunity ${ }^{20}$

18. See text accompanying notes 69-77 infra.

19. This statement is based on the assumption of a policy of fee shifting for the successful plaintiff rather than the prevailing party. The soundness of this policy and the implications of a two-way street are discussed at note 270 and accompanying text, infra.

20. The doctrine of sovereign immunity is not one, but several doctrines: (1) the common law immunity of states from nonconsensual suit in their own courts or the courts of another state; (2) the eleventh amendment jurisdictional bar to private suits against states in federal courts; (3) the federal government's immunity from nonconsensual suit; (4) international sovereign immunity. While this Comment concerns the second category, reference will be made to decisional law in the third category as some of the concepts are similar and significant case authorities are cited in both contexts. See $3 \mathrm{~K}$. Davis, AdMInistrative Law Treatise $\S 27.02$, at $548 \mathrm{n} .1$ (1958) ("No difference is discernible in modern law between suits against states in the federal courts, and suits against the Umited States in federal courts."). There is at least one significant difference, however, since considerations of federalism are not as prevalent in the third category. 
and its constitutional stature under the eleventh amendment is reflected in the Supreme Court's decision in Edelman v. Jordan. ${ }^{21}$ Simply stated, the amendment, for present purposes, means that a federal court cannot have original jurisdiction over a suit against a state by any private person. On the other hand, a state may be reached to some extent through suits against its officers. The essential question, then, is what constitutes a suit against a state. The issue has been much debated; it has been said that "[t]he subject is not free from casuistry."22 The apparent differences in the judicial interpretations reflect tensions between considerations involving the rights of individuals, the needs and prerogatives of the state, and the role of the courts. ${ }^{23}$ The following sections examine the forces which have shaped the development of the American doctrine and the present scope of the eleventh amendment jurisdictional bar.

\section{A. Sovereign Immunity and the States-Origins}

The origins of the American doctrine of sovereign immunity lie in the Enghish common $1 \mathrm{aw}^{24}$ which provided the King with absolute personal immunity. The Enghish doctrine suggests the interplay of three basic considerations: an abstract notion of the impropriety of suing the Crown without its consent; a concern for controlling interference with the Treasury and the Crown's officers; and a concern for providing remedies to do justice. ${ }^{25}$ It appears that the latter factor generally

21. 415 U.S. 651 (1974).

22. Larson v. Domestic \& Foreign Commerce Corp., 337 U.S. 682, 708 (1949) (Frankfurter, J., dissenting).

23. See id. at 708-09.

24. See generally C. JAcoBs, The Eleventh AMENDMENT and Sovereign IMMUNITY $4-7$ (1972) [hereinafter cited as JACOBs]; Jaffe, Suits Against Governments and Officers: Sovereign Immunity, 77 HaRv. L. Rev. 1 (1963) [hereinafter cited as Jaffe, Sovereign Immunity]; Mathis, The Eleventh Amendment: Adoption and Interpretation, 2 GA. L. REv. 207, 207-10 (1968) [hereinafter cited as Mathis, Eleventh Amendment Interpretation]; United States v. Lee, 106 U.S. 196, 226 (1882) (dissenting opinion).

25. It is evident that the King's subjects were not without legal redress against the Crown or its officers. Although actions against the Crown by name required a petition of right, which the King could deny, it appears that such petitions were approved so long as there appeared to be a prima facie legal claim, and various procedures were made available for the recovery of property wrongfully withheld by the Crown and for claims on monetary obligations of the Crown. See Jaffe, Sovereign Immunity 6-7. (For a more restrictive view of the availability of these remedies see Chisholm v. Georgia, 2 U.S .(2 Dall.) 419, 436-45 (1793) (Iredell, J., dissenting).) In addition, damage actions against the Crown's officers for trespass were permissible, and certiorari provided an injunctive remedy. See Jaffe, Sovereign Immunity 15-16. On the other hand, recovery on monetary claims in nonconsensual suits against the Crown's officers was more difficult. This seems to be largely the result of a reluctance to imterfere with discretionary acts of officers. Thus, there arose a distinction between actions that would interfere with discretionary 
prevailed, and that the doctrine of sovereign immunity was largely a natter of procedure-that of selecting the proper mode of redress from among those permitted by the Crown. ${ }^{26}$

The adoption of the doctrine of sovereign immunity by the American states seems anomalous since there was no King to whom the immunity could pass; the people theoretically were sovereign. ${ }^{27}$ However, while immunity as an abstract principle was followed in England partly in deference to the King, it also served to preserve the Crown's control and to prevent undue interference with the government. In view of the precarious fimancial condition of the American states at the time of the revolution, ${ }^{28}$ it is not surprising, in retrospect, that the states limited judicial remedies against themselves. With the ratification of the Constitution and the interposition of an external governmental structure upon the states, another dimension was added to the problem through the establishment of the federal court system. While it was mevitable that some state sovereignty was relinquished to the federal government, the emergence of a new judiciary not controlled by the states posed a direct threat to state sovereignty.

Despite significant expressions of concern regarding the states' susceptibility to suits in federal courts, article III of the Constitution was passed in a form which did not preclude such suits, perhaps because of disclaimers to the contrary by advocates of the federal government. ${ }^{20}$ Article III by its terms extended the judicial power of the United States

acts involving the Treasury, for which mandamus would not issue, and actions to compel an official to perform a statutorily prescribed duty. Id. at 17-18. A similar distinction was adopted in the American use of the writ of mandamus. See notes 53, 102-103 and accompanying text, infra.

26. See JACOBS 6; Jaffe, Sovereign Immunity 18-19; McCormack, Federalism and Section 1983: Limitations on Judicial Enforcement of Constitutional Protection, Part I, 60 VA. L. REV. 1, 36-37 (1974) [hereinafter cited as McCormack, Federalism and Section 1983].

27. This view was emphatically expressed by Justice Wilson in Chisholm v. Georgia, 2 U.S. (2 Dall.) 419, 453-60 (1793), but the decision was soon overruled by the enactment of the eleventh amendment. See text accompanying notes 32-37 infra. The American adoption of the immunity doctrine seems all the more anomalous since the citizens of the states apparently lost certain remedies that were available against the Crown. See JACoBs 6-7; Jaffe, Sovereign Immunity 19; United States v. Lee, 106 U.S. 196, 226 (1882) (dissenting opimion).

28. See JaBoBs 8; Jaffe, Sovereign Immunity 19.

29. See 1 C. Warren, The Supreme Court in Untred Statzs History 91 (rev. ed. 1932) [hereinafter cited as 1 WARREN]; The FeDERALIST No. 81 (A. Haimilon). For a textual analysis see JACOBS 9-26. Jacobs concludes that "the legislative history of the Constitution hardly warrants the conclusion drawn by some that there was a general understanding, at the time of ratification, that the states would retain their sovereign immunity." Id. at 40. But see Cullison, Interpretation of the Eleventh Amendment (A Case of the White Knight's Green Whiskers), 5 Hous. L. REV. 1, 7 (1967) [hereinafter cited as Culhison]; 1 WARREN 91. 
to controversies "between a State and Citizens of another State."30 This clause was interpreted hiterally in Chisholm $v$. Georgia, ${ }^{31}$ where a majority of the Supreme Court held that assumpsit lay against Georgia in a suit brought by a citizen of another state. ${ }^{32}$ This precipitated the ratification of the eleventh amendment preventing suits against a state by citizens of another state or of a foreign state. Almost one hundred years later, the Court in Hans $v$. Louisian $a^{33}$ held that the eleventh amendment prevented suits against a state by citizens of that state.

While there is no doubt that the eleventh amendment was a direct result of the Chisholm decision, ${ }^{34}$ the primary concerns which prompted its enactment are not quite as apparent. It is likely that the response was prompted by several factors: a concern for liabilities on state indebtedness; ${ }^{35}$ and a concern for state sovereignty, with the dual consideration of suits by "mere" individuals and by authority of another government ${ }^{36}$ - a fear of national supremacy and the reduction of states to "Inere corporations." The considerations were reflected in the judicial interpretations that followed, but the scope of the eleventh anendment was not easily settled. Two major questions remained: first, whether the eleventh annendment applied to cases arising under the Constitution or laws of the United States, and second, whether the amendment applied to suits brought by citizens of the defendant state.

\section{B. The Development of Doctrine}

One of the first judicial interpretations of the eleventh amendment came in Cohens $v$. Virginia. ${ }^{38}$ The matter before the Court was a writ of error to a judgment of a Virginia court against a citizen of that state. The state nroved to dismiss the writ for want of jurisdiction, two of the

30. U.S. CoNST. art. III, $\$ 2$.

31. 2 U.S. (2 Dall.) 419 (1793).

32. Justice Iredell, the lone dissenter, asserted that the statutory grant of jurisdiction was not intended to override the common law which required a petition of right in such cases, and that the Court could not change the law. Id. at 429-53. Justice Iredell thus viewed the states as retaining sovereignty as to matters falling within the common law. While not deciding the scope of Congress' powers under the judiciary article, he suggested that Congress would not have the power to allow a compulsive suit against a state for the recovery of money. Id. at 449-50. He recognized, however, that the state must defer to the government when it acts under its special authority under the Constitution. $I d$. at $435-36,448$. While Justice Iredell's dissent was vindicated with the ratification of the eleventh amendment, the effect of the amendment has been more restrictive than the scope of the dissent.

33. 134 U.S. 1 (1890).

34. E.g., JACOBS, supra note 24, at 64-65.

35. 1 WARREN, supra note 29 , at 99.

36. Id. at 92-93.

37. Id.

38. 19 U.S. (6 Wheat.) 264 (1821). 
grounds being that the eleventh amendment precluded the state froin being a defendant, and that no writ of error lies from the Supreme Court to a state court. ${ }^{39}$ The Court, per Chief Justice Marshall, held the eleventh amendment inapplicable on the alternative grounds that a writ of error was not a suit against the state and that the writ, if contrued as a suit, was not within the amendment because it was not coinmenced or prosecuted "by a citizen of another State, or by a citizen or subject of any foreign state." ${ }^{\prime 0}$ This latter construction of the amendment was subsequently repudiated, ${ }^{41}$ but Marshall's opinion remains instructive in its reflection of the opposing considerations involved in these cases. The controversy involved not only a citizen against a state, but also a conflict between a law of Virginia and an act of Congress, and also a dispute concerning the respective roles of the state and national courts. While the inain issue before the Court was that of Supreme Court review of state court decisions, Chief Justice Marshall also suggested a narrow reading of the eleventh amendment. After noting that the historic purpose of the amendment was to protect states from their creditors, Marshall stated:

A general interest might well be felt in leaving to a State the full power of consulting its convenience in the adjustment of its debts, or of other claims upon it; but no interest could be felt in so changing the relations between the whole and its parts, and so strip the government of the neans of protecting, by the instrumentality of its courts, the constitution and laws from active violation. ${ }^{42}$

A second Marshall interpretation of the eleventh amendment came in Osborn v. Bank of the United States. ${ }^{43}$ The bank, a federally chartered corporation, brought suit against Osborn in his capacity as State Treasurer of Ohio to enjoin the execution of a state tax on the bank and to recover taxes previously collected in violation of a preliminary injunction. Noting that the proceeding was in substance against the state, Marshall preceded his analysis of the jurisdictional issue by stressing the need for asserting jurisdiction in order to prevent state officials from interfering with federal laws:

39. Marshall disposed of the issue of Supreme Court review of state court decisions by referring to Martin v. Hunter's Lessee, 14 U.S. (1 Wheat.) 304 (1816). See 19 U.S. ( 6 Wheat.) at 423.

40. 19 U.S. (6 Wheat.) at 412.

41. Hans v. Louisiana, 134 U.S. 1 (1890).

42. 19 U.S. (6 Wheat.) at 407. Marshall's analysis had the effect of putting citizens and noncitizens in the same position with respect to debt claims, but created an apparent disparity with respect to federal question claims. Marshall's analysis, however, would have permitted the construction that the eleventh amendment was limited to nonfederal question suits.

43. 22 U.S. (9 Wheat.) 738 (1824). 
[A denial of jurisdiction would affect cases] where the government is in the exercise of its best established and most essential powers . ... It asserts, that the agents of a State, alleging the authority of a law, void in itself, because repugnant to the constitution, may arrest the execution of any law in the United States. ${ }^{44}$

Marshall then concluded that the eleventh amendment is limited to those suits in which a state is a party of record. So construed, "the true question is, not one of jurisdiction, but whether, in the exercise of its jurisdiction, the court ought to make a decree against the defendants." While the Court later rejected the position that the eleventh amendment prohibits only suits to which the state is a named party, Osborn opened the way for suits against states by way of suits against state officials. ${ }^{46}$

In contrast with the Marshall opinions, the eleventh amendment was interpreted quite differently in later cases involving attempts to enforce a state's debt obligations where there was an alleged violation of the contracts clause ${ }^{47}$ of the Constitution. In Louisiana v. Jumel ${ }^{48}$ the Court demed rehef where bondholders sued state officials for compliance with a state statute, asking specifically for the disbursement of tax monies collected for payment on the bond indebtedness and for further tax collections as required by the statute. In denying rehief the Court noted that the requested relief would act directly on the state, and would require the officials to "act contrary to the positive orders of the supreme political powcr of the State." ${ }^{49}$ The Court in Jumel undoubtedly was influenced by the inplications of granting relief. The complaint sought relief not only for the individual plaintiff, but would inure to the benefit of others similarly situated. The Court refused to becoine involved, stating that

[t]he remedy sought ... . would require the court to assume all the executive authority of the State . . . and to supervise the conduct of all persons charged with any official duty in respect to [the state's indebtedness]. The political power cannot be thus ousted of its jurisdiction and the judiciary set in its place. ${ }^{50}$

The Court's concern was not only with administrative problems of effecting rehief. As noted by Justices Field and Harlan in dissenting

44. Id. at 847 .

45. Id. at 858 .

46. The Court awarded restitution of money that had already been collected by the state. Since the money had not passed into the general funds of the treasury, the judgment might be viewed as not touching the state's funds. This would seem, however, to be a distinction based on form rather than substance.

47. "No State shall . . . pass any . . . Law impairing the Obligation of Contracts ... . U.S. ConsT. art. I, § 10.

48. 107 U.S. 711 (1882).

49. Id. at 721 .

50. Id. at 727-28. 
opinions, the duties of the state officers toward bondholders remained in force and the officials inight be judicially compelled to perform those ministerial duties. ${ }^{51}$ The greater concern was that of interfering with the political affairs of the state by compelling it to specifically perform its contract, thus foreclosing alternative courses of action. ${ }^{52}$

Jumel did not have the effect of preventing suits against state officials, but the utility of such suits was sharply limited. ${ }^{53}$ In re Ayres ${ }^{54}$ represents a further limitation on sucl1 actions. In In re Ayres the Court refused to enjoin Virginia's attorneys from instituting proceedings to collect taxes from persons who had tendered bond coupons in payment as permitted by contract. Characterizing the suit as one based on a breach of contract to which the state was a party, the Court held that the suit was in effect a suit against the state and thus prohibited by the eleventh ainendment. ${ }^{55}$ In re Ayres thus made it difficult, if not impossible, to enjoin state officers froin enforcing unconstitutional legislation. The Court's attitude toward the eleventh amendment is reflected in the following statement:

The very object and purpose of the 11 th Amendment were to prevent the indignity of subjecting a State to the coercive process of judicial tribunals at the instance of private parties. It was thought to be neither becoming nor convenient that . . . the course of their public policy and the administration of their public affairs should be subject to and controlled by the mandates of judicial tribunals without their consent, and in favor of individual interests. ${ }^{.6}$

51. Id. at 737, 763-64.

52. Enforceability of a decree may have been another concern. See L. JAFPE, Judicial Control of AdmInistrative Action 218-19 (1965) [hereinafter cited as JAFFE, JUDICIAL CONTROL].

53. State officials could still be sued in tort and mandamus could still be issued to compel the performance of purely ministerial acts which the offieer had a personal duty to perform. In addition, if property in which the state had an interest came before the court in the regular course of judicial administration, without being forcibly taken from the government, the Court could still render a decree affecting that property. If the state became a party, either by suing or by interveution, it would be treated as any other party. Cunninghain v. Macon \& B.R.R., 109 U.S. 446, 451-52 (1883).

54. 123 U.S. 443 (1887). In re Ayres was one of the Virginia Coupon Cases. For a discussion of an earlier decision, Poindexter v. Greenhow, 114 U.S. 270 (1885), see note 64 infra.

55. The plaintiffs in In re Ayres were aliens who held coupons for resale to taxpayers, who were Virginia citizens. Since the suit was held to be against the state it fell within the eleventh amendment. Suits by citizens of the same state were not then prohibited by the eleventh amendinent.

The result in In re Ayres might be explained on the basis that the plaintiffs had no need for equitable relief since the taxpayers had a valid defense based on Poindexter v. Greenhow (discussed in note 64 infra). See McCormack, Federalism and Section 1983, supra note 26 , at 41 . A defense based on the coupons when the state sued to collect taxes was subsequeutly recognized in McGahey v. Virginia, 135 U.S. 662 (1890).

56. 123 U.S. at 505. 
It is hardly surprising, then, that in Hans $v$. Louisiana ${ }^{57}$ the Court held that the judicial power of the United States under the federal question clause of article III does not extend to suits instituted against a state by its own citizens. Since Hans the eleventh amendment has consistently been construed as precluding federal jurisdiction of all suits against a state by its citizens without its consent. ${ }^{58}$ The result has been explained on the following basis:

Behind the words of the constitutional provisions are postulates which limit and control. . . . There is . . the postulate that States of the Union, still possessing attributes of sovereignty, shall be immune froin suits, without their consent, save where there has been a "surrender of this immunity in the plan of the convention." The Federalist, No. 81.59

The early development of the eleventh amendment immunity doctrine shows that although the states' concern over their indebtedness was a major factor, the problem was much broader, and a particularly strong postulate was that of federalism and limited national powers. Also significant was the Court's reluctance to issue decrees which would, in effect, impose the judiciary's control on matters which arguably were within the discretionary control of other branches of government. Thus, the Court was reluctant to render decrees which would leave the state with only a single course of action, as in the specific performance of contracts. As against these considerations which militated in favor of the immumity of the state there was the concern, especially on the part of Chief Justice Marshall, for promoting the role of the federal judiciary as a unifying force in protecting the laws of the nation, and the concern for providing remedies for individuals seeking redress against governments. ${ }^{60}$

57. 134 U.S. 1 (1890). Hans was an action by a citizen of Lonisiana against that state to recover the amount of coupons on bonds issued by the state. Subsequent to the issue of the bonds a new state constitution was adopted which provided that the coupons be remitted and the interest taxes be transferred to defray the expenses of the state. Federal question jurisdiction was predicated on violation of the contracts clause of the Constitution.

58. The latest affirmance of this view is Edelman v. Jordan, 415 U.S. 651 (1974). This view, however, is not unanimously held by the Court. Justice Breunan takes the view that neither article III nor the eleventh anendment restricts the jurisdiction of federal courts over suits by citizens of a state against their state. Id. at 687 (dissenting opinion); Einployees v. Department of Pub. Health \& Welfare, 411 U.S. 279, 315-22 (1973) (dissenting opimion). Justices Marshall and Stewart view the restriction as inherent in article III. Id. at 290-94 (concurring opinion).

59. Principality of Monaco v. Mississippi, 292 U.S. 313, 322-23 (1934).

Although not inentioned in the cases, Hans is less prejudicial to the interests of citizens of a state against which a suit is being brought than the already-existing doctrine was against non-citizens' interests, because citizens at least have access to the state's political process, whereas non-citizens do not. This, of course, does not justify the Hans decision.

60. In United States v. Lee, 106 U.S. 196 (1882), the Court, in holding for the 


\section{Ex parte Young}

In 1908 the Supreme Court's landmark decision in Ex parte Young ${ }^{61}$ marked another change in the immunity doctrine. The controversy involved an attempt by the Attorney General of Minnesota to enforce a statute which was alleged to establish noncompensatory railroad rates in violation of the fourteenth amendment. The Court held that the eleventh amendment did not bar the federal circuit court from taking jurisdiction over a suit by a Minnesota citizen to enjoin a state official from acting pursuant to an unconstitutional statute. ${ }^{62}$ The Court reasoned that an official acting under an unconstitutional statute "comes into conflict with the superior authority of ... [the] Constitution, and . . . is . . . stripped of his official or representative character" and thus is personally responsible for his conduct. ${ }^{63}$ The officer's liability was thus predicated on a common law tort-where the conduct was not legally justified, the official was personally liable. So construed, Ex parte Young is consistent with the line of decisional law reaching back to the English common law that liolds that an officer must justify his conduct, and where state authority is raised as a defense, the court must liave the power to examine the validity of the authority. ${ }^{64}$ It is apparent, lowever,

plaintiffs, stated that the defense of government immunity seems to be opposed to all the principles upon which the rights of the citizen, when brought in collision with the acts of the government, must be determined. In such cases there is no safety for the citizen, except in the protection of the judicial tribunals . ...

Id. at 218-19.

61. 209 U.S. 123 (1908).

62. The permissibility of injunctive relief against an officer of a sovereign was not a new concept. It was available under the English law, see Jaffe, Sovereign Immunity, supra note 24, at 16-18, and followed in the United States. Sce, e.g., Board of Liquidation v. McComb, 92 U.S. 531 (1875); Davis v. Gray, 83 U.S. (16 Wall.) 203 (1872); Osborn v. Bank of the United States, 22 U.S. (9 Wheat.) 738 (1824). But with the change in judicial attitudes toward sovereign immunity, injunctive relief which worked in substance against the state was barred. See, e.g., In re Ayes, 123 U.S. 443 (1887) (discussed at notes 54-56 supra).

63. 209 U.S. at 159-60.

64. Under the English law the Crown's officers were suable for trespass. See, e.g., Jaffe, Sovereign Immunity, supra note 24, at 15-16. Under American law the personal tort liability of the official was used as a basis for allowing plaintiffs to recover property which was wrongfully taken from them or held against their legal claim by the offieer on behalf of the sovereign. A significant early decision came in United States v. Lee, 106 U.S. 196 (1882), in which the plaintiff was successful in an action in ejectment against two federal officers who held property under color of title in the United States. (For an expression of the Court's dissatisfaction with the immunity doctrine, see note 60 supra). Although the Court apparently based its decision on a theory of uneonstitutional taking of property, the case may also be explained as a tort action-where the holding of property is not legally justified, the sovereign's immunity does not protect the agent. See Larson v. Domestic \& Foreign Commerce Corp., 337 U.S. 682, 716-18 (1949) (Frankfurter, J., dissenting). Lee was followed in Tindal v. Wesley, 167 U.S. 204 (1897), a suit against sțate offiçials to reçover possession of real property. The tort theory was also 
that the Court expanded the scope of common law tort liability and thus created a federal cause of action; it is not clear that the officer's conduct-threatening prosecutions under an unconstitutional statuteconstituted a tort under state law. ${ }^{65}$

Ex parte Young quite obviously was an attempt to provide a means of federal judicial control over the conduct of the states. The urgency of the need for control is reflected in the Court's implication of a federal cause of action; witlout a private remedy for unlawful state action, the substance of the fourteenth amendment and the supremacy clause of the Constitution would be seriously undermined. It is also quite clear, however, that the Court created a fiction in maintaining that the suit was not, in substance, against the state. But, as stated by one commentator, "in perspective the doctrine of Ex parte Young seems indispensable to the establishment of constitutional government and the rule of law."

adopted in Poindexter v. Greenhow, 114 U.S. 270 (1885), one of the Virginia Conpon Cases involving Virginia's refusal to honor its commitment to accept coupons from state bonds in payment of taxes. Upon plaintiff's refusal to pay taxes in legal tender, the state officers levied upon and seized personal property belonging to the plaintiff. In Poindexter the plaintiffs brought an action against the state officer to recover their property and for damages. The Court held that the law, which required tender in money and thereby unconstitutionally impaired the state's contractual obligation to accept coupons in payınent for taxes, was not sufficient justification for the officer's seizure of plaintiff's property. While the officer was presumably personally liable, it is clear that the effect of the decision was to hinder the state's revenue collecting program. In a later decision, however, the Court refused to enjoin the state from collecting taxes in legal tender. See notes 54-56 and accompanying text, supra. For a subsequent restriction of the tort theory, see Larson v. Domestic \& Foreign Commerce Corp., 337 U.S. 682 (1949), discussed at note 92 infra.

65. See Hart, The Relations Between State and Federal Law, 54 Colum. L. REv. 489, 524 (1954) [hereinafter cited as Hart, State and Federal Law]; Hill, Constitutional Remedies, 69 Colum. L. Rev. 1111, 1126-27, 1139 (1969); P. Bator, P. Mishikin, D. Shapiro \& H. Wechsler, Hart and Wechsler's The Federal CoURTs and tHe FeDERAL System 935 (2d ed. 1973) [hereinafter cited as HART AND WeCHSLER].

Professor Hart put the matter as follows: "By almost imperceptible steps [the Court] appears to have come to treat the remedy of injunction as conferred directly by federal law for any abuse of state authority which in the view of federal law ought to be remediable." Hart, State and Federal Law 524.

The Court in Young was not willing to admit as much, stating the matter as follows:

II] must be remembered that jurisdiction of this general character has, in fact, been exercised by Federal courts from the time of Osborn v. United States Bank up to the present; the only difference in regard to the case of Osborn and the case in hand being that in this case the injury complained of is the threatened commencement of suits, civil or criminal, to enforce the act, instead of, as in the Osborn case, an actual and direct trespass upon or interference with tangible property. ... The difference between an actual and direct interference with tangible property and the enjoining of state officers from enforcing an unconstitutional act, is not of a radical nature, and does not extend, in truth, the jurisdiction of the courts over the subject matter.

209 U.S. at 167.

66. C. Wright, Federal CourTs 186 (2d ed. 1970). 
Ex parte Young thus established a landmark in constitutional law enabling a federal court to apply private remedies against the officers of a state. ${ }^{67}$ However, it is arguable that it slould have gone further to limit the eleventh ainendment to its literal terms or to nonfederal question cases.

Ex parte Young was a suit for injunctive relief, but it had a broader impact; the natural tendency was to atteinpt to expand the doctrine. However, pleas for other forms of relief again raise questions of eleventh amendment jurisdictional limitations because of the inescapable conclusion that many suits against state officials are, in effect, suits against the state. The question is not whether the suit is really against the state, but whether the relief sought against the official acts in such manner against the state so as to invoke the jurisdictional bar of the eleventh annendinent. ${ }^{68}$ Particularly troublesome are suits whicli would have some impact on the state treasury or otherwise require some form of affirmative action by the state. Yet it is clear that suits against. state officials typically result in financial consequences to the state or otherwise require some corrective measures by the official on behalf of the state. The question of the permissibility of attorneys' fees against the official thus depends in part on the principles underlying the decisions in which the relief granted has, in fact, an impact upon the state.

\section{Edelman v. Jordan and the Scope of Equitable Remedies}

The scope of permissible relief under Ex parte Young was put into sharp focus in cases involving challenges to state administration of federally funded welfare prograins. It is clear that state officials may be enjoined froin operating prograins that are violative of the Constitution or federal regulations, but the lower courts were in disagreement on whether equitable relief under Ex parte Young could include the "restitution" of welfare benefits wrongfully withheld. ${ }^{69}$ The issue was settled

67. In a similar exercise of judicial power in the context of suits against federal officers, the Court in Bivens v. Six Unknown Named Agents of Federal Bureau of Narcotics, 403 U.S. 388 (1971), implied a constitutionally-derived private right of action against federal officers for violation of the fourth amendment. Bivens, like Young, was a private suit against an officer of a government. The Court largely ignored potential probleins of federal governmental immunity that might arise if personal liability of federal officers created undue interference with governmental operations. The focus, instead, was on the individual officer. As in Young the implication of a federal cause of action may be explained on the basis of the apparent inadequacy of state remedies and the lack of federal legislation.

68. Cf. JAFFe, Judictal Contror, supra note 52, at 221-22.

69. Compare Rothstein v. Wyman, 467 F.2d 226 (2d Cir. 1972), cert. denied, 41 U.S. 921 (1973) (award of retroạctive benefits impermissible under eleventh amendment), with Jordan v. Weaver, 472 F.2d 985 (7th Cir. 1973), rev'd sub nom. Edelman v. Jordan, 415 U.S. 651 (1974) (circuit court held "equitable restitution" permissible under eleventh amendment; reversed by Supreine Court). 
in Edelman v. Jordan, ${ }^{70}$ in which the Supreme Court held that a federal court's remedial power under Ex parte Young does not include a retroactive award that requires payment of funds from the state treasury. ${ }^{71}$ In a broadly written opinion the Court first examined the origins of the eleventh amendment and reaffirmed the Hans ${ }^{72}$ interpretation that an unconsenting state is immune from suit brought in federal court by its own citizens, and that a suit may be barred by the eleventh amendment even if the state is not a party of record. ${ }^{73}$ The Court then reasserted the doctrine that a suit seeking to impose liabilities that must be paid from the state treasury is a suit against the state. ${ }^{74}$ Although certain decrees under the doctrine of Ex parte Young are not without effect on the state treasury, the Court distinguished such cases on the basis that the fiscal consequences in such cases were the necessary result of compliance with decrees which were prospective in nature. ${ }^{75}$ The Court maintamed that "[s]uch an ancillary effect on the state treasury is a permissible and often an mevitable consequence of the principle announced in Ex parte Young . . . ." The Court then held that a federal courts remedial power under Ex parte Young is limited to prospective injunctive relief. ${ }^{77}$

The Court thus distinguished between two general classes of remedies: (1) affirmative relief which would compel the state, through its officers, to perforn specific acts, and (2) injunctive relief which prohibits a state official from acting in a particular manner. While affirmative relief is prohibited by the eleventh amendment, imjunctive relief is constitutionally permissible notwithstanding any "ancillary" effect on the state treasury. The distinction is not purely seinantic because the state in the second situation theoretically lias a choice of action and therefore is not compelled to give specific relief at the instance of a private plaintiff.

\section{Affirmative Relief}

Edelman's proscription of monetary awards to be paid from state funds had its doctrinal origins in the formative period of the American

70. 415 U.S. 651 (1974) (5-4 decision).

71. Id. at 677.

72. Hans v. Louisiana, 134 U.S. 1 (1890), discussed at notes 57-58 and accompanying text, supra.

73. 415 U.S. at $660-63$.

74. Id. at 663-64. For a discussion of the development of this doctrine, see text accompanying notes 78-96 infra.

75. 415 U.S. at 667-68. For a discussion of this "Ancillary Financial Consequences" doctrine, see text accompanying notes 97-121 infra.

76. 415 U.S. at 668.

77. Id. at 677 . 
states when liabilities on state indebtedness were a major concern. Louisiana $v$. Jumel, ${ }^{78}$ in which bondholders sought to compel state officers to honor the state's bond obligations, is a foundation for eleventh amendment immumity. Another foundation case for the doctrine is Smith $v$. Reeves, ${ }^{79}$ which involved a diversity action by a feclerally chartered corporation against the Treasurer of the State of California to recover allegedly illegal taxes. Although state law provided a procedure for recovery, the Court held in Reeves that the suit nonetheless was a prohibited suit against the state since "the relief sought is a judgment against ... [the] officer in his official capacity; and that judgnent would coinpel him to pay out of the public funds in the treasury of the State a certain sum of inoney." 80 The Court distinguished the earlier cases which lad held that an action would lie to recover specific property in the possession of the officer, or to compel the officer to perform a plain ministerial duty. ${ }^{81}$ Rather than analogizing to those cases, the Court found that the situation in Reeves was similar in "material aspects" to Louisiana v. Jumel. To be sure, there was one significant difference between the cases. In Reeves there was a state remedy for a inatter especially within the province of the state; ${ }^{82}$ in Jumel a constitutional claim was presented, but a state remedy was highly unlikely. The basic common thread, however, was that both cases involved an attempt to compel the state to release funds wrongfully withheld by the state.

Smith $v$. Reeves and its progeny thus established the primciples that a suit for a monetary claim against the state was prohibited by the eleventh amendment and that a state's consent to suit in its own courts did not constitute consent to suit in federal court unless the latter consent was clearly manifested..$^{33}$ In the context of state tax controversies Reeves is unexceptionable since a state remedy is available, and the result is consistent with the traditional deference accorded the states in

78. 107 U.S. 711 (1883). See notes 48-53 and text accompanying, supra.

79. 178 U.S. 436 (1900).

80. Id. at 439 (einphasis in original).

81. Id.

82. The Court noted:

[I]t was competent for the state to couple with its consent to be sued on account of taxes alleged to have been exacted under illegal assessments made by the state board, the condition that the suit be brought in one of its own courts. Such legislation ought to be deemed a part of the taxing system of the State.... Id. at 445 .

83. E.g., Edelman v. Jordan, 415 U.S. 651, 673 (1974); Kennecott Copper Corp. v. State Tax Comm'n, 327 U.S. 573 (1946); Ford Motor Co. v. Department of Treasury, 323 U.S. 459 (1945); Great N. Life Ins. Co. v. Read, 322 U.S. 47 (1944); see generally Comment, Implied Waiver of a State's Eleventh Amendment Immunity, 1974 DUKE L.J. 925, 928-29 (1974). 
their tax administration. ${ }^{84}$ In addition, it is clear that when a state remedy is available, the state's constitutional immunity under the eleventh amendment does not result from a concern over the imposition of liabilities on a state. Reeves or its progeny are typically cited, lrowever, in cases denying relief involving nontax monetary claims against the state. ${ }^{85}$ Reconciliation of the latter decisions with Reeves forces the conclusion that the principle of Reeves is not the prohibition of monetary claims per se, nor a requirement of deference in tax matters. The more consistent principle seems to be that the eleventh amendment prohibits a federal court from issumg a decree compelling a state official to perform a non-ministerial act. In addition, the sovereign state retains the prerogative of restricting relief and the cloice of judicial forums.

The aforementioned primciples are quite evident in the suits denying specific performance of contracts, ${ }^{86}$ the context in whicl much of the eleventh amendment doctrine developed. Courts have been concerned not only with potential financial burdens on the state, but also with the propriety of judicial compulsion of state conduct. ${ }^{87}$ The celebrated case of Larson v. Domestic and Foreign Commerce Corp. ${ }^{88}$ illustrates this point in the context of suits against federal officers. Larson involved a suit by a private corporation against an official of the War Assets Administration for breach of contract of sale. The plaintiff sought to enjom the official from selling the goods to another person and also a declaration of the validity of the contract which it held with the War Assets Administration. Although the plaintiff did not explicitly seek specific performance, it is clear that this was the intent simce a damage action was available in the Court of Claims. ${ }^{89}$ In a far-reaching

84. See, e.g., Kennecott Copper Corp. v. State Tax Comm'n, 327 U.S. 573 (1946); Ford Motor Co. v. Dept. of Treasury of Indiana, 323 U.S. 459 (1945); Great N. Life Ins. Co. v. Read, 322 U.S. 47 (1945).

85. E.g., Louisiana v. Jumel, 107 U.S. 711 (1882).

86. A striking example of a suit for specific performance is Louisiana v. Jumel, 107 U.S. 711 (1882), which also involved a monetary claim. See notes 48-53 and accompanying text, supra. Other major cases of this type included North Carolina v. Temple, 134 U.S. 22 (1890); Hagood v. Southern, 117 U.S. 52 (1886). In re Ayres, 123 U.S. 443 (1887), was not brought as a suit for specific performance, but was interpreted as such. See text accompanying notes 54-56 supra. There have been few recent suits for specific performance but it is clear that they would fail. See Charles Simkin \& Sons, Inc. v. State Univ. Constr. Fund, 352 F. Supp. 177 (S.D.N.Y. 1973), aff'd mem., 496 F.2d 1393 (2d Cir. 1973); Aerojet-General Corp. v. Askew, 453 F.2d 819 (5th Cir. 1971), cert. denied, 409 U.S. 892 (1972); American Hosp. Supply Corp. v. York County Institution Dist., 123 F. Supp. 187 (M.D. Pa. 1954).

87. See, e.g., In re Ayres, 123 U.S. 443, 505 (1887) [discussed at text accompanying notes 54-56 supra]; Hagood v. Southern, 117 U.S. 52 (1886); Louisiana v. Jumel, 107 U.S. 711 (1883).

88. 337 U.S. 682 (1949).

89. Id. at 703 n.27. See the concurring opinion by Justice Douglas. Id. at 705 . 
opinion the Court concluded:

[I]t is one thing [for Congress] to provide a method by which a citizen may be compensated for a wrong done to him by the Government. It is a far different matter to permit a court to exercise its compulsive powers to restrain the Government from acting, or to compel it to act. . . . The Government . . . cannot be stopped in its tracks by any plaintiff who presents a disputed question of property or contract right..$^{00}$

Larson, in this context, sets forth two propositions: first, a sovereign has the prerogative of specifying the mode of relief; ${ }^{91}$ second, a court has an obligation to respect the sovereign's choice even if other relief might otherwise be appropriate and within the court's powers. Larson, however, did not turn entirely on a choice of remedies. The possibility of any remedy at all depended on the nature of the officer's conduct-only where the act was undertaken pursuant to unconstitutional authority or beyond the officer's statutory authority was plaintiff entitled to maintain the action. ${ }^{22}$ Moreover, even in the latter situations judicial relief, in the absence of statutory authorization, was not assured, for the Court added in its famous footnote 11:

Of course, a suit may fail, as one against the sovereign, even if it is claimed that the officer being sued has acted unconstitutionally or

90. Id. at 704.

91. Id. at 703-05; and see the dissent by Jnstice Frankfurter:

When there is such a special remedy [so as to displace by statute those that otherwise would be at plaintiff's command] the suit against the officer is barred not because he enjoys the immunity of the sovereign but because the sovereign can constitutionally change the traditional rules of liability for the tort of the agent by providing a fair substitute.

Id. at 722 .

92. The Court stated that smce the sovereign may not be sued, the action to be restrained or directed must not be the act of the sovereign. 337 U.S. at 693 . A suit against the officer would not be a suit against the sovereign in only two classes of cases. First, "where the officer's powers are limited by statute, his actions beyond those limitations are considered individual and not sovereign actions." Id. at 689. Also, where the statute or order conferring power upon the officer is alleged to be unconstitutional, the officer's conduct is personal and not the sovereign's because "power has been conferred in form but the grant is lacking in substance because of its constitutional invalidity." Id. at 690. If the case did not fall within one of these categories the officer could be personally liable under the "general law of torts," but the officer's conduct could not be enjomed or directed since "it is also the action of the sovereign." Id. at 695.

This distinction between the torts of the sovereign and the torts of the agent serves further to immunize the sovereign from liability. In effect the sovereign is never liable; where there has been an actionable wrong, it is that of the agent. While the Court did not expressly overrule United States v. Lee, 106 U.S. 196 (1882) (discussed at notes 60, 64 supra), the Larson Court's formulation limits the availability of relief to recover property since recovery would be barred when the agent was acting erroneously but withim statutory authority. To this effect see Knight v. New York, 443 F.2d 415 (2d Cir. 1971). 
beyond his statutory powers, if the relief requested can not be granted by merely ordering the cessation of the conduct complained of but will require affirmative action by the sovereign or the disposition of unquestionably sovereign property. North Carolina v. Temple. ${ }^{93}$

Although the Court did not foreclose the possibility of affirmative relief in cases involving constitutional claims, ${ }^{94}$ Larson's impact has been to reinforce the preclusion of non-injunctive rehef in suits against state $^{95}$ as well as federal officers. Consistent witl the breadth of the Larson opinion there is a "general rule" that "relief sought nominally against an officer is in fact against the sovereign if the decree would operate against the latter." ${ }^{\text {g日 }}$ Ex parte Young is an exception to the

93. 337 U.S. at 691 n.11. North Carolina v. Temple, 134 U.S. 22 (1890), decided the same day as Hans v. Louisiana, 134 U.S. 1 (1890), was another case in which the plaintiff sought to compel the state to comply with a debt funding statute. The Court held, under the authority of Hans, that a suit against the state or its officers by a citizen of the state was prohibited by the eleventh amendment even when a federal claim was presented.

94. The Court stated:

There are limits, of course. Under our Constitutional system, certain rights are protected against governmeutal action and, if such rights are infringed by the actions of officers of the Government, it is proper that the courts have the power to grant relief against those actions.

337 U.S. at 704.

95. E.g., Knight v. New York, 443 F.2d 415 (2d Cir. 1971) (citing Larson); Landman v. Royster, 354 F. Supp. 1302 (E.D. Va. 1973) (citing Larson).

96. Hawaï v. Gordon, 373 U.S. 57, 58 (1963) (per curiam). See also Dugan v Rank, 372 U.S. 609 (1963):

The general rule is that a suit is against the sovereign if "the judgment sought would expend itself on the public treasury or domain, or interfere with the public administration," Land v. Dollar, 330 U.S. 731, 738 (1947), or if the effect of the judgment would be "to restrain the Government from acting, or to compel it to act." Larson v. Domestic \& Foreign Corp., supra, 337 U.S. at 704; . . . Ex parte New York, 256 U.S. 490, 502 . . . (1921).

Id. at 620 .

The strength of the immunity doctrine is illustrated in numerous suits against federal officers where a "general rule" has been invoked despite the possibility of narrower grounds of decision such as: (a) the availability of alternative forms of relief, e.g., Mine Safety Appliances Co. v. Forrestal, 326 U.S. 371 (1945) (injunction against withholding of contractual payments by federal official denied where plaintiff had a remedy in Tax Court); cf. Dugan v. Rank, 372 U.S. 609 (1963) (injunction against impoundinent of water by federal officials denied; damage remedy available); (b) undue interfereuce with governmental activities, e.g., Larson v. Domestic \& Foreign Commerce Corp., 337 U.S. 682 (1949) (specific performance on contract with government sales agency denied; damage remedy available); Dugan v. Rank, 372 U.S. 609 (1963) (injunction against impoundment of water by federal officials denied; damage remedy available); or (c) inappropriateness of a judicial remedy, e.g., Hawaii v. Gordon, 373 U.S. 57 (1963) (suit to conpel the Director of the Bureau of the Budget to convey certain lands to the State of Hawaii if not "needed by the United States"). Similarly, dismissals of certain suits against state officers could be better explained on grounds that a more appropriate state forum was available for the particular type of action. E.g., Kennecott Copper Corp. v. State Tax Comm'n, 327 U.S. 573 (1946) (state provided judicial procedure for resolution of tax disputes); Knight v. New York, 443 F.2d 415 (2d Cir. 1971) (state law provided for adjudication of rights concerning property appropriat- 
general rule and permits injunctive relief even though it obviously affects the state.

\section{Equitable Relief and "Ancillary" Financial Consequences to the State}

While the controversy in Ex parte Young ${ }^{97}$ did not involve the state treasury, the resultant decisions under the principle of that case have, in many instances, had an effect on the state treasury and may appear to be inconsistent with Edelman's proscription of monetary relief. A case in point is Georgia Railroad \& Banking Co. v. Redwine, ${ }^{98}$ which involved a state's attempted nullification of certain tax exemptions theretofore granted in plaintiff's corporate charter by the state. The plaintiff filed suit to enjoin the State Revenue Commissioner from assessing or collecting ad valorem taxes contrary to its legislative charter, alleging that the state's action was violative of the contracts clause of the Constitution. The Supreme Court, finding that remedies at law were inadequate and that the suit was not for specific performance by the state, ${ }^{, 9}$ held that the district court had jurisdiction in a suit for mjunctive relief. Although the Court's reasoning followed directly from Ex parte Young, the state's direct pecumary interest in the matter and the fact that the state was a party to the contract dictated a need to distinguish In re Ayres, ${ }^{100}$ which had held to the contrary on similar facts prior to Ex parte Young. Young, of course, had overruled the presumption made in In re Ayres that a suit against an officer, except in limited circumstaltces, was a suit against the state. But the holding in Redwine, despite the disclaimer that the suit was not against the state, dictated the result that the contract would be enforced and, consequently, the state's fimancial plans would be disrupted.

ed for public uses). While such cases suggest that the "general rule" is excessively broad, they also illustrate the courts' reluctance to grant relief not authorized by a sovereign.

97. 209 U.S. 123 (1908).

98. 342 U.S. 299 (1952).

99. Id. at 303-04. "[A]ppellant's complaint is not framed as a suit for specific performance." Id. at 304 (emphasis added).

100. 123 U.S. 443 (1887). In In re Ayres holders of coupons of bonds of the State of Virginia sought to enjoin state officials from instituting proceedings to collect taxes from persons who attempted, pursuant to the bond obligation, to tender coupons in payment of taxes. The suit was characterized as one for specific performance against the state. See text accompanying notes 54-56 supra. The Court's need to distinguish In re Ayres indicates, in light of Ex parte Young, the Court's reluctance to recognize explicitly the fiction created in Young.

McCormack, Federalism and Section 1983, supra note 26, at $47-48$, suggests that Redwine is consistent with In re Ayres because of the different magnitudes of the amount in controversy in the respective cases-Redwine involved an individual plaintiff, while In re Ayres would have affected a large class. 'The magintude of state indebtedness was indeed a major concern during the formative years of the immunity doctrine, but the size of the plaintiff's claim seems an inappropriate basis for decision. 
The Redwine decision demonstrates that a plaintiff who alleges unconstitutionality of state action may obtain relief even if the state's interests are adversely affected. The issue is one of the appropriateness of the relief requested. A suit for injunctive relief is more likely to be entertained than a suit requesting affirmative action against the state, ${ }^{\mathbf{1 0 1}}$ although the state may be no less interested in the consequences of an injunction. The traditional basis for this distinction lay in the proposition that it was not proper for a court to issue mandaunus for an action that was within the official's discretionary powers, ${ }^{102}$ or completely outside the officer's powers; ${ }^{103}$ in either case it is clear that the object of the mandamus would be to require action by the state through its agent. Ex parte Young retained the distinction between injunctive and affirmative relief and inaintained that the suit was one against the officer as an individual and not as an agent of the state. A presumptive basis for the distinction between injunctive and affirmative relief requiring state action is that an injunction creates less interference with the sovereign's activities. ${ }^{104}$ An alternative basis for the distinction is that the granting of non-injunctive relief compels the state to act in a particular manner, thus foreclosing alternative courses that the state might otherwise prefer and which are within its prerogative.

In recent years the distinction between imjunctive relief and affirmative relief has become blurred as courts have sought not only to enjom unconstitutional conduct but also, in the ancillary exercise of their equitable jurisdiction, to grant other appropriate relief. While such decisions may result in an impact upon the state treasury, they are not imconsistent with Edelman v. Jordan. For example, where a state acts against an individual, the judiciary must have the authority to compel the state to act in a manner consistent with the Constitution. Under the doctrine of Ex parte Young, the federal courts have the authority to enjoin state officials from acting in violation of the Constitution. If the state is to continue its activities consistently with the Constitution it may be necessary for the state to undertake affirmative, corrective measures. Nonetheless, the choice is the state's. For example, in Goldberg $v$. Kelley ${ }^{105}$ it was held that procedural due process requires the availability of a pre-termination evidentiary hearing for welfare recipients. As a practical matter the state will be required to institute such a procedure.

101. See, e.g., Georgia R.R. \& Banking Co. v. Redwine, 342 U.S. 299, 304 (1952). 102. Cunningham v. Macon \& B.R.R., 109 U.S. 446, 453 (1883); Board of Liquidation v. McComb, 92 U.S. 531, 541 (1875).

103. Hagood v. Southern, 117 U.S. 52, 69-70 (1886); Cunningham v. Macon \& B.R.R. 109 U.S. 446 (1883); Louisiana v. Jumel, 107 U.S. 711, 727-28 (1883).

104. See Comment, Monetary Remedies Against the State in Federal Question Cases, 68 Nw. U.L. Rev. 544 (1973).

105. 397 U.S. 254 (1970). 
Nonetheless, the state theoretically retains a choice: it can offer pretermination evidentiary hearings as part of its welfare program, or it can choose to have no program at all. ${ }^{108}$ Similarly, when a state invokes its judicial process against an individual it is required to act consistently with the requireinents of due process and, for example, may be required to provide counsel for indigent defendants. ${ }^{107}$ The state has the choice of providing counsel or not proceeding against such defendants. Similarly, where the claim is inade that a state has subjected an individual to unconstitutional conditions during otherwise lawful detention or incarceration, ${ }^{108}$ the court states that the individual may not be detamed under such conditions; the affirmative duty to correct deficiencies arises after the state makes the decision to use the facilities. In each of the situations described above the state has acted against the constitutional prohibition that "[n]o State shall ... deprive any person of life, liberty, or property, without due process of law . . . ."100 The injunctive relief authorized under the doctrine of Ex parte Young effectuates this constitutional command. The court inay, indeed, order more. ${ }^{110} \mathrm{But}$ it is implicit in such orders that the state is required to comply only if it chooses to continue in its otherwise legitimate state function. So long as the court does not command that the state must do both, the relief remains injunctive-the state may not proceed unless it conforms with constitutional standards.

The court and state are in a similar posture when the controversy involves a federal-state program using federal funds. For example, in Rosado v. Wyman, ${ }^{111}$ which involved a statutory challenge to a New York welfare law, the plaintiffs requested declaratory and injunctive relief on the ground that the state statute was imcompatible with the federal standards. The Court stated:

106. While a state might not be required to provide welfare assistance, if it chooses to do so it must comport with due process requirements. E.g., Goldberg v. Kelly, 397 U.S. 254 (1970) (pre-termination evidentiary hearing). Similarly, it must not discriminate in providing benefits. E.g., Graham v. Richardson, 403 U.S. 365 (1971) (residency durational requirements for welfare benefits for aliens violative of equal protection).

107. E.g., Miranda v. Arizona, 384 U.S. 436 (1966) (counsel for custodial interrogation); Douglas v. California, 372 U.S. 353 (1963) (counsel for initial appeal of criminal conviction); Gideon v. Wainwright, 372 U.S. 335 (1963) (counsel for indigents charged with serious crime). Although a constitutional defense raiscd by an individual is not a "suit against the state" within the meaning of the eleventh amendment, the example is used as another illustration of the relationship between the substantive claim, the relief granted, and the ensuing effects.

108. E.g., Inmates of Suffolk County Jail v. Eisenstadt, 360 F. Supp. 676 (D. Mass. 1973), affd, 494 F.2d 1196 (1st Cir. 1974); Martarella v. Kelly, 349 F. Supp. 575 (S.D.N.Y. 1972); Newman v. Alabama, 349 F. Supp. 278 (M.D. Ala. 1972).

109. U.S. CoNsT, amend. XIV.

110. See, e.g., cases cited at note 108 supra.

111. 397 U.S. 397 (1970). 
We have considered and rejected the argument that a federal court is without power to review state welfare provisions or prohibit the use of federal funds by the States in view of the fact that Congress has lodged in the Department of HEW the power to cut off federal funds for noncompliance with statutory requirements. We are most reluctant to assume Congress lias closed the avenue of effective judicial review . . . . While [King v. Smith, 392 U.S. 309 (1968)] did not advert specifically to the remedial problem, the unarticulated premise was that the State had alternative choices of assuming the additional cost of paying benefits to families with substitute fathers or not using federal funds to pay welfare benefits according to a plan that was inconsistent with federal requirements. ${ }^{112}$

Finding the state program to be incompatible with federal standards, the Court held that the plaintiffs were entitled to declaratory relief and an injunction against the payment of federal momes unless the state developed a conforming plan within a reasonable period of time. ${ }^{113}$ The nature of the complaint and the relief stem from the substantive claim that the state program inappropriately used federal funds. Since the state's participation in the program was voluntary, the Court could not compel the payment of funds; the proper remedy was to enjoin the inconsistent use of federal funds. Congress presumably could have provided for other remedial relief as one of the conditions for state participation, but it lrad not done so. The Court noted in addition that the state is "in no way prohibited from using only state funds according to whatever plan it chooses, providing it violates no provision of the Constitution." ${ }^{114}$ While the state was put to a difficult choice, the formal mode of relief remained injunctive rather than mandatory.

Similarly, in constitutional challenges to state welfare programs on equal protection grounds, relief is frained in terms of a prohibitive rather than affirmative command. ${ }^{115}$ This again resnlts from the nature of the fourteenth amendment claim of denial of equal protection of the

112. Id. at $420-21$.

113. The Court noted that the

incremental cost to the State, assuming a desire to comply with [the federal statute] is massive .... Accordingly, we remand the case to the District Court to fix a date that will afford New York an opportunity to revise its program in accordance with the requirements of the [federal statute] if the State wishes to do so. The District Court shall retain jurisdiction to review ... or, should New York choose not to submit a revamped program by the predetermined date, issue its order restraining the further use of federal monies pursuant to the present statute.

Id. at 421-22.

114. Id. at 420.

115. E.g., Graham v. Richardson, 403 U.S. 365 (1971) (state statute that denies welfare benefits to resident aliens and one that denies them to aliens who have not resided in the United States for a specified number of years held violative of the equal protection clause of the fourteenth amendment). 
laws. The constitutional mandate is satisfied if the state discontinues discriminatory administration of the laws. If the state chooses to continue a program it may, as a result of the court's declaration, find it necessary to take affirmative measures. Nonetheless, the court's decree remains prohibitory, and what follows remains to be decided by the state.

The cases discussed above which in practical effect will require affirmative action by the state are not inconsistent with Edelman $v$. Jordan since Edelman does not bar "affirmative" relief which is a "necessary consequence of compliance in the future with a substantive federal question determination" when the defendants are under a "court-imposed obligation to conform to a different [i.e., federal or constitutional] standard."116 The "court-imposed obligation" arises when the court has declared the standard; if the state chooses to continue the particular activity it must comply with the standard. For example, the Seventh Circuit, in Rodriguez v. Swank, ${ }^{117}$ cited the above quoted Edelman language in affirming a supplemental District Court order which provided that after a prescribed future date an ehigible public aid applicant whose application was not processed in conformity with the court's decree would be entitled to compensatory damages. ${ }^{118}$ This result is consistent with Edelman and the eleventh amendment on the theory that where the state continues to act after a court has declared the constitutional or federal standard, the state has waived its immunity to federal judicial control.

Some federal courts, at least before Edelman, were quite willing to take affirmative steps in the initial action to ensure compliance with constitutional standards, particularly in cases challenging conditions in mental health facilities. ${ }^{119}$ However, in the absence of a constitutional requirement that such facilities be provided by a state, and in the absence of a federal program which has conditioned state activities in the area, it is difficult to discern a basis for such relief in light of

116. 415 U.S. 651,668 (1974).

117. 496 F.2d 1110 (7th Cir. 1974), cert. denied, 419 U.S. 885 (1974).

118. Id. at 1111.

119. E.g., New York State Ass'n for Retarded Children, Inc. v. Rockefeller, 357 F. Supp. 752 (E.D.N.Y. 1973); Wyatt v. Stickney, 344 F. Supp. 373 (M.D. Ala. 1972). In Rockefeller the district court went beyond Rosado to order specific relief in conjunction with a preliminary injunction in a controversy involving alleged existence of unconstitutional conditions in the operation of a state facility for the inentally retarded. The court stated that "under the facts of this case, money is not an obstacle to the defendants doing what the court intends to direct" since "[f]or all practical purposes, the state must ultimately meet the requirements of the Department of Health, Education and Welfare or lose the substantial federal assistance which is granted for the care of the mentally retarded." 357 F. Supp. at 765 . The court thus assumed that the state would choose to contimue operations with HEW support. 
Edelman and its doctrinal foundations. The courts' willingness to undertake affirmative steps is also apparent in the school desegregation cases, ${ }^{120}$ but they, too, provide only tenuous support for the federal courts' remedial powers under the eleventh amendment. School desegregation cases are distinguishable because they involve county school systems and therefore are unaffected by the eleventh amendment even though the state indirectly may be implicated and state funds may be involved. ${ }^{121}$

\section{Summary}

Courts and commentators have offered numerous explanations for the rationale underlying the doctrine of sovereign immunity. A consistent basis for the American doctrine has been the protection of the states' fiscal integrity. ${ }^{122}$ More generally, it has been said that the "real policy basis for the doctrine of sovereign immunity today" is that the "subjugation of the state and federal governments to private litigation might constitute a serious interference . . . with their control over their respective instrumentalities, funds, and property." ${ }^{123}$ As a variant of such a policy, state-federal welfare programs have been characterized as a "scheme of cooperative federalism" with which federal courts should be

120. E.g., Swann v. Board of Educ., 402 U.S. 1 (1971); Green v. School Board, 391 U.S. 430 (1968); Griffin v. School Board, 377 U.S. 218 (1964); Brown v. Board of Educ., 349 U.S. 294 (1955). In Griffin the Court stated that "the District Court may, if necessary to prevent further discrimination, require the Supervisors to exercise the power that is theirs to levy taxes to raise funds adequate to reopen, operate, and maintain without racial discrimination a public school system in Prince Edward County . . . ." 377 U.S. at 233.

121. In Griffin the state clearly was implicated, but the suit was permitted under the doctrine of Ex parte Young, 377 U.S. at 228, and the doctrine that the eleventh amendinent does not apply to suits against counties. Id. at 228; Lincoln County v. Luning, 133 U.S. 529 (1890). Although county action is state action for purposes of the fourteenth amendinent, a county defendant is not necessarily a state defendant for purposes of the eleventh ainendment. Edelman v. Jordan, 415 U.S. 651, 667 n.12 (1974). All parties to the Griffin litigation treated the suit as one against the state. See Briefs of Counsel, 12 L.Ed.2d 1105-09 (1964). Whether a suit is in fact only against a county in a given suit may not be entirely clear since one test of whether the eleventh anendment applies is the manner in which a political subdivision is financed. Harris v. Tooele County School Dist., 471 F.2d 218, 220 (10th Cir. 1973). In Griffin the reopening of the school presumably would have involved some state funds since other public schools received state support. See 377 U.S. at 223. But since the Court did not order such support the eleventh amendinent was inapplicable.

122. E.g., Jordan v. Gilligan, 500 F.2d 701, 706 (6th Cir.), petition for cert. filed, 43 U.S.L.W. 3240 (U.S. Oct. 9, 1974) (No. 74-403); Maryland v. Wirtz, 392 U.S. 183, 201 (1968) (dissenting opinion). The "fiscal integrity" argument is, of course, debatable. See, e.g., Comment, Monetary Remedies Against the State in Federal Question Cases, 68 Nw. U.L. REv. 544, 564 (1973).

123. Block, Suits Against Government Officers and the Sovereign Immunity Doctrine, 59 HARV. L. REv. 1060, 1061 (1946). 
loath to interfere. ${ }^{124}$ Similar notions of federalism have been prevalent in the area of state tax controversies. As a general principle, "federalism" suggests that the national government, and especially the courts, abstain froin undue interference with the legitimate activities of the states. Aside froin such policy considerations, however, sovereign immunity of the states has been embodied in the eleventh ainendment as a limitation of federal judicial power: "legal irresponsibility was written into the Eleventh Amendment." 125 This constitutional indoctrination has sharply restricted the federal courts' remedial powers in suits against state officers.

Although Edelman's limitation of Ex parte Young to prospective injunctive relief runs counter to contemporary norms of justice, it is doctrinally consistent with Young and its progeny. The prohibition of the eleventh amendment is not merely against the imposition of fiscal burdens on a state, but rather the coercive effect of compelling affirmative action by the state. The state clearly is involved when injunctive as well as affirmative relief is ordered, but the distinction is significant in several respects. Where affirmative relief is ordered, the state is clearly given no choice of action. Where the rehef is injunctive, however, the state official is only prohibited from engaging in unlawful conduct; the state retains the option of finding other solutions. Thus, the limitation to injunctive relief results in less of a shift in power from the states to the federal judiciary and to that extent is consistent with the eleventh amendment. And as a practical matter, the distinction affords a convenient nneans of limiting the effect of the eleventh amendment while avoiding total judicial abrogation of the amendment.

II

\section{Nonstatutory Fee Awards Against State Officials}

Prior to Edelman v. Jordan little critical analysis had been undertaken concerning the eleventh amendment implications of fee awards against state officials sued under the doctrine of Ex parte Young. A few courts ${ }^{126}$ held that the eleventh amendment barred fee shifting against state officials, but the majority followed the lead of Sims v. Amos ${ }^{127}$ in allowing attorneys' fees that ultimately would be paid by the state. Sims involved a reapportionment class suit against the Secretary of State,

124. Jefferson v. Hackney, 406 U.S. 535, 542 (1972); King v. Smith, 392 U.S. 309, 316 (1968); Rothstein v. Wyman, 467 F.2d 226, 232 (2d Cir. 1972).

125. Keifer \& Keifer v. Reconstr. Fin. Corp., 306 U.S. 381, 388 (1939).

126. Undergraduate Student Ass'n v. Peltason, 359 F. Supp. 320, 323-24 (N.D. Ill. 1973); Sincock v. Obara, 320 F. Supp. 1098 (D. Del. 1970); Hergenreter v. Hayden, 295 F. Supp. 251 (D. Kan. 1968).

127. 340 F. Supp. 691 (M.D. Ala.), aff'd mem., 409 U.S. 942 (1972). 
Attorney General, and Governor of Alabama. In the opinion dealing with attorneys' fees, the three judge district court dealt primarily with the general equity theories of attorneys' fee awards and based the award on either the class benefit or "private attorney general" doctrine, although the "obdurate behavior" standard was also considered applicable. ${ }^{128}$ The immunity issue was summarily treated in a footnote:

Individuals who, as officers of a state, are clothed with some duty with regard to a law of the state which contravenes the Constitution of the Urited States, may be restrained by injunction, and in such a case the state has no power to impart to its officers any immunity from such injunction or froin its consequences, including the court costs incident thereto. Ex parte Young. ${ }^{129}$

Although this decision was subsequently affirmed by the Supreme Court, ${ }^{130}$ the summary nature of the affirmance detracts from its value as bimding precedent. ${ }^{131}$ Nonetheless, Sims generated a considerable following. In Gates v. Collier, ${ }^{132}$ the Fifth Circuit placed partial rehance on Sims, but went beyond Sims in affirming the district court's decree directing that the fees be paid "from funds which the Mississippi legislature, at its 1973 session, may appropriate for the operation of the Mississippi State Pemitentiary." Circuit in Brandenburger v. Thompson, ${ }^{134}$ where the court lield that the plaintiffs were entitled to attorneys' fees, apparently as against the state officials in their official capacity. Another variation on the Sims theme is presented by La Raza Unida $v$. Volpe, ${ }^{135}$ where the court awarded

128. Id. at 693-95.

129. Id. at 694 n.8 (citation omitted).

130. 409 U.S. 942 (1972).

131. A summary affirmance is not of the same precedent value as an opinion of the Supreme Court dealing with the question on the merits. Edelman v. Jordan, 415 U.S. 651, 671 (1974); Richardson v. Ramirez, 418 U.S. 24, 83 n.27 (Marshall, J., dissenting). See also Hagans v. Lavine, 415 U.S. 528, 533 n.5 (1974). In addition, the Court in Edelman stated that when questions of constitutional law are involved, the principle of stare decisis is less binding on the Court thau it is in other areas of law. 415 U.S. at 671. The value of Sims v. Amos as precedent is even more questionable because the preliminary print of the Court's affirmance apparently referred only to the district court opinion dealing with the substantive reapportionment issue, and not the separate attorneys' fee decision. The bound version of volume 409 of the United States Reports, however, states that the attorneys' fees decision was also affirmed. 409 U.S. at 942 . This situation was noted by the Sixth Circuit in Jordan v. Gilligan, 500 F.2d 701, 706-07 (6th Cir. 1974) (appeal pending).

132. 489 F.2d 298 (1973), aff d, 501 F.2d 1291 (5th Cir. 1974).

133. Id. at 303 (quoting the trial court). The award was based on a theory of "equitable restitution" from the state appropriations. The court noted in addition that the trial court also had the power to assess fees against the individual defendants. Id. at 30203.

134. 494 F.2d 885 (9th Cir. 1974).

135. 57 F.R.D. 94 (N.D. Cal. 1972), appeal dismissed, Civil No. 73-1145 (9th Cir. May 29, 1975) (non-appealable order). 
attorneys' fees against the Chief Highway Engineer of California in his individual capacity under the Sims rationale while noting that the individual defendant, as a state officer, would be entitled to reimbursement by the employing public agency under state law. ${ }^{136}$

The trend, illustrated by Gates, Brandenburger and $L a$ Raza, toward fee awards that would be paid from state funds was halted by the Supreme Court's decision in Edelman v. Jordan. ${ }^{137}$ Although Edelman did not involve an issue of attorneys' fees, the opinion denying, on eleventh amendinent grounds, an award of retroactive welfare benefits contained two najor points which bear directly on the fee issue. First, the Court held that a suit seeking to impose a hability for past breaches of legal duty and which must be paid from public funds in the state treasury is barred by the eleventh amendment, even if the state is not a party of record; ${ }^{138}$ lowever, monetary consequences ancillary to prospective injunctive relief are permissible. ${ }^{139}$ Second, the Court held that the state had not "constructively consented" to suit in federal court by participating in the federally financed welfare program. ${ }^{140}$ Edelman thus portends an eleventh amendment bar to attorneys' fee awards that are to be paid from state funds. Accordingly, the Third, Fifth and Sixth Circuits $^{141}$ have read Edelman as barring awards of attorneys' fees against state officials in their official capacity or agamst agencies clothed with the state's immunity. The Second Circuit, ${ }^{142}$ however, has upheld awards of attorneys' fees against state officials in their official capacity under the "ancillary effect" exception of Edelman. In addition, the First Circuit $^{143}$ has taken the position that attorneys' fees may be assessed

136. CAL. Gov'T CoDE $\S \S 825-25.6$ (West 1966); see 57 F.R.D. at 101 n.10.

137. 415 U.S. 651 (1974).

138. Id. at 663 . This rule is discussed at text accompanying notes $78-85$, supra.

139. 415 U.S. at 667-68. This rule is discussed at notes 97-118 supra and accompanying text.

140. 415 U.S. at 672-77.

141. Third Circuit: Skehan v. Board of Trustees, 501 F.2d 31 (3d Cir.), petition for cert. filed, 43 U.S.L.W. 3296 (U.S. Nov. 8, 1974) (No. 74-558).

Fifth Circuit: Named Individual Members of the San Antonio Conservation Soc'y v. Texas Highway Dep't, 496 F.2d 1017, 1026 (5th Cir.), rehearing granted, (Aug. 29, 1974) (Attorneys' fee issue), petition for cert. on other grounds filed, 43 U.S.L.W. 3308 (U.S. Nov. 20, 1974) (No. 74-621).

Sixth Circuit: Taylor v. Perini, 503 F.2d 899 (6th Cir. 1974), petition for cert. filed, 43 U.S.L.W. 3281 (U.S. Oct. 30, 1974) (No. 74-506); Jordan v. Gilligan, 500 F.2d 701 (6th Cir.), petition for cert. filed, 43 U.S.L.W. 3240 (U.S. Oct. 9, 1974) (No. 74403). In Milburn v. Huecker, 500 F.2d 1279 (6th Cir. 1974), the court remanded for reconsideration of the appropriateness of awarding attorneys' fees because the trial court's denial of fees was not supported by sufficient findings of fact; no mention of the eleventh amendment as it pertains to this issue was made by the court.

142. Jordan v. Fusari, 496 F.2d 646 (2d Cir. 1974); Class v. Norton, 505 F.2d 123 (2d Cir. 1974).

143. Souza v. Travisono, 43 U.S.L.W. 2402 (1st Cir. Mar. 11, 1975), petition for 
against state officials as an incident of its regular jurisdiction.

\section{A. Assessment of Fees Against the State or Its Officers in Their Official Capacities}

\section{Attorneys' Fees and the "State Funds" Rule}

In Jordan v. Gilligan, ${ }^{144}$ the Sixth Circuit, in reversing a juJgment awarding attorneys' fees against the state, followed Edelman's affirmance of the rule that the eleventh amendment bars "a suit by private parties seeking to impose a liability which must be paid from public funds in the state treasury . . .."145 The court applied the theory that the purpose of the eleventh amendment is to preserve the fiscal integrity of the states, ${ }^{146}$ asserting that "[a]ny award of attorneys' fees, whether against the State . . . or its officials, vitally affects the rights and interests of the State in preserving its revenues." ${ }^{147}$ In following Edelman's line of analysis the court distinguished between retroactive and prospective relief by classifying attorneys' fees as an "award which is 'measured in terms of a monetary loss resulting from a past breach of a legal duty on the part of the defendant state officials." "148

The court's fiscal integrity rationale, to the extent it reflects a concern for the financial burden on the state, is unpersuasive since permissible prospective imjunctive relief can have far wider impact on a state's treasury than a fee award. ${ }^{149}$ Rather, the impermissible aspect of the attorneys' fee award lies in its compulsory effect in requirimg a positive act by the state. As discussed above, ${ }^{150}$ a remedy accorded a private party against a state is permissible under Edelman and its predecessors only if the state is ordered to do nothing more than discontinue the prohibited conduct. Any further action that a state may

cert. filed, 43 U.S.L.W. 3639 (U.S. May 1, 1975) (No. 74-1372). The court held that attorneys' fees should be afforded the same treatment as the costs of appeal which were permitted to be assessed against state officials in Boston Chapter, N.A.A.C.P., Inc. v. Beecher, 504 F.2d 1017 (1st Cir. 1974). The court in Beecher relied heavily on Fairmont Creamery Co. v. Minnesota, 275 U.S. 70 (1927), where the Supreme Court held that sovereign immunity did not protect a state against a judgment for costs where the court had valid jurisdiction over the state. Fairmont Creamery involved an appeal from a state court decision, and federal court jurisdiction over the state was clear; the case is not persuasive authority for the exercise of similar powers over a state in cases within the doctrine of Ex parte Young, where the state is not a party to the litigation.

144. 500 F.2d 701 (6th Cir.), petition for cert. filed, 43 U.S.L.W. 3240 (U.S. Oct. 9, 1974) (No. 74-403).

145. Edelman v. Jordan, 415 U.S. 651, 663 (1974).

146. 500 F.2d at 706 .

147. Id. at 704-05.

148. Id. at 710, quoting Edelman v. Jordan, 415 U.S. 651, 668 (1974).

149. See text accoinpanying notes 98-116 supra. See also Edelman v. Jordan, 415 U.S. 651, 667-68 (1974).

150. See text accompanying notes 105-15 supra. 
choose to take is the result of its decision to continue its activity in conformance with constitutional or federal standards. An award of attorneys' fees clearly does not leave to the state the option that is imphicit in the prospective injunctive relief deemed permissible by Edelman.

The same reasoning applies when state officials or state agencies ${ }^{161}$ are ordered to pay fee awards from state funds under the control of the official or agency. ${ }^{152}$ Such orders are no inore avoidable when directed against officials than when directed against the state itself. Thus, the award in Gates v. Collier ${ }^{153}$ of attorneys' fees to be paid from the operating funds of the Mississippi State Penitentiary clearly contradicts the state funds rule of Edelman. Moreover, the same result should obtain irrespective of whether the defendant has discretionary control of the funds allocated to the agency. This follows from the rule against judicial orders to compel officials to perform discretionary functions ${ }^{164}$

151. If the judgment will reduce state funds the agency will generally be considered part of the state for eleventh amendment purposes. E.g., George R. Whitten, Jr., Inc. v. State Univ. Constr. Fund, 493 F.2d 177, 180 (1st Cir. 1974); Harris v. Tooele County School Dist., 471 F.2d 218, 220 (10th Cir. 1973). But see Gates v. Collier, 489 F.2d 298 (5th Cir. 1973), aff'd, 501 F.2d 1291 (5th Cir. 1974). The state-financing test, however is not conclusive. Other factors are also relevant, e.g., whether the organization performs a state obligation or function. Hopkins v. Clemson Agric. College, 221 U.S. 636 (1911); George R. Whitten, Jr., Inc. v. State Univ. Constr. Fund, 493 F.2d 177, 179-80 (1st Cir. 1974); S. J. Groves \& Sons v. New Jersey Turnpike Authority, 268 F. Supp. 568, 579 (D.N.J. 1967); Krisel v. Duran, 258 F. Supp. 845, 849 (S.D.N.Y. 1966). A county is not within the eleventh amendment, Lincoln County v. Luning, 133 U.S. 529 (1890), but complications may arise when a county organization is financed with state funds. Compare Harris v. Tooele County School Dist., 471 F.2d 218 (10th Cir. 1973), with Griffin v. County School Board of Prince Edward County, 377 U.S. 218 (1964).

Whether a political subdivision is clothed with the state's immunity generally is a matter of state law. E.g., Harris v. Tooele County School Dist., 471 F.2d 218, 220 (10th Cir. 1973); Grady County v. Dickerson, 257 F.2d 369 (5th Cir.), cert. denied, 358 U.S. 909 (1958). State law, however, is not dispositive of the eleventh amendment issue. If the substantive claim involves a substantial federal question within Congress' powers then the state entity's waiver of the eleventh ainendment defense is a federal question. Parden v. Terminal Ry. of the Ala. State Docks Dep't, 377 U.S. 184, 196 (1964); Petty v. Tennessee-Missouri Bridge Comm'n, 359 U.S. 275 (1959). Waiver of eleventh amendment immunity regarding an award of attorneys' fees is discussed in text accompanying notes 233-252, infra.

152. E.g., Named Individual Members of the San Antonio Conservation Soc'y v. Texas Highway Dep't, 496 F.2d 1017, 1026 n.12 (5th Cir.), rehearing granted, (Aug. 29, 1974) (attorneys' fee issue), petition for cert. on other grounds filed, 43 U.S.L.W. 3308 (U.S. Nov. 20, 1974) (No. 74-621). Since the Osborn nominal party rule has long been discarded, see text accompanying notes $45-46$ supra, the suit may be treated as one against the state even if the state is not a named defendant.

153. 489 F.2d 298 (1973), affd, 501 F.2d 1291 (5th Cir. 1974).

154. Courts are usually reluctant to impose conduct on an official when he supposedly has discretion to act otherwise. See note 53 and accompanying text supra. See also Mayor of Philadelphia v. Educational Equality League, 415 U.S. 605, 613-15 (1974). 
and, more fundamentally, the fact that although the doctrine of $E x$ parte Young brings state officials within a federal court's jurisdiction nominally in their individual capacities, the court's power to direct the officials' activities is limited to the effectuation of injunctive relief. ${ }^{155}$

\section{Attorneys' Fees as an "Ancillary Effect"}

The Second Circuit ${ }^{150}$ has esclrewed the state funds test and has instead classified a fee award as a permissible adjunct to injunctive relief. Whether or not this is a tenable construction of Edelman's "ancillary effect" exception depends on the context in which it is used. A fee award can be viewed in two basic nodes: compensatory and deterrent. In the deterrent mode, the fee award can be applied as a punitive device for past misconduct and as a threatened sanction for future misconduct. The latter aspect was emphasized in Class $v$. Norton, ${ }^{157}$ which involved a contempt proceeding against a state welfare official for noncompliance with the terms of a court order issued three years earlier calling for timely processing of applications for welfare assistance under Aid to Families with Dependent Children (AFDC), ${ }^{158}$ a federally assisted program. The district court chose not to issue the requested contempt sanctions, but instead directed a detailed implementation plan, to which was added $\$ 1,000$ for attorney's fees and costs to the appellees. The Second Circuit, in affirming the award against the official in his official capacity, stated:

[W]e underline the forward-looking, deterrent nature of this award. Indeed, even without regard to the "ancillary effect" exception of Edelman, we would have no difficulty reconciling the award with the retrospective thrust of Edelman as a "necessary result of attempts to gain compliance with a decree which by its terms was prospective in nature." Rodriguez v. Swank. ${ }^{159}$

In Rodriguez v. Swank, ${ }^{160}$ the proceedings in the lower court, as in Norton, imvolved a motion for supplemental remedies to enforce an earlier order. The Seventh Circuit affirmed an order that the state pay $\$ 100$ as coinpensatory damages to any eligible AFDC applicant whose application was not timely processed in the future.

155. But see Comment, Suits Against State Officials: Attorneys' Fees and the Eleventh Amendment, 53 TEx. L. REv. 85, 97 (1974) [hereinafter cited as Comment, Attorneys Fees and the Eleventh Amendment] (award should be "permissible under Edelman as an 'ancillary effect" "). The "ancillary effect" exception is discussed at notes 156-71 infra and accompanying text.

156. Class v. Norton, 505 F.2d 123 (2d Cir. 1974); Jordan v. Fusari, 496 F.2d 646, 651 (2d Cir. 1974) (dictum).

157. 505 F.2d 123 (2d Cir. 1974).

158. 42 U.S.C. $\$ \$ 601$ et seq. (1970).

159. 505 F.2d 123, 127 (2d Cir. 1974) (citation omitted).

160. 496 F.2d 1110 (7th Cir. 1974). 
Both Norton and Rodriguez, then, involved the imposition of a monetary award on the basis of a state official's noncompliance with a prior judicial order. The question is whether noncompliance with a judicial order is sufficient to overcome the eleventh amendment barrier and permit a monetary award to be paid to the plamtiff from state funds. There is no doubt that the state officer-the nominal defendant-could be held individually liable since a conditional monetary sanction is a traditional method of enforcing injunctions. ${ }^{101}$ The Edelman decision suggests that sucl a remedy may be permissible even if payable from state funds. In seeking to distinguish compensation that would be retroactive from the time of the initial suit, and therefore barred, from that permitted by the "ancillary effect" principle, the Court noted that retroactive benefits would be based on conduct at a time when the state officer "was under no court-imposed obligation to conform to a different standard." 102 If, as the Court suggests, restitution could be awarded for losses incurred while the officer was under a court-imposed obligation, an award of attorneys' fees would likewise be warranted. The award of attorneys' fees in sucl a case would not only be compensatory, but would also effectuate compliance with the prospective decree. As noted by the court in Rodriguez, the power to issue injunctions would be meaningless if the injunction were unenforceable. ${ }^{103}$ The requirement of a means of enforcement, however, would not require the conclusion that the state, rather than the individual, should be assessed.

On the other liand, it is clear that the state itself is the object of the suit; it is necessary to sue the state officer as the nominal defendant because of the state's eleventh amendment immunity. It is also clear that an injunction against a state officer can liave a direct and immediate impact upon the state; otlier consequences may also flow, depending on the state's choice of subsequent conduct. ${ }^{10.4}$ Sucl incidents of the injunctive relief are witlin Edelman's category of "ancillary effects." The money judgments for noncompliance with prior judicial orders are similarly "ancillary effects" since they flow directly from the order granting injunctive relief. Where the state has once violated the injunction, the indicia of future noncompliance are sufficiently strong that the assessment of monetary sanctions can be considered as a necessary consequence of the prior injunction. Monetary awards in this situation may

161. United States v. United Mine Workers, 330 U.S. 258, 303-05 (1947); id. at 330-35 (Black and Douglas, JJ., concurring in part and dissenting in part).

162. 415 U.S. 651,668 (1974).

163. 496 F.2d 1110, 1112-13 (7th Cir. 1974). See also United States v. United Mine Workers, 330 U.S. 258, 303-05 (1947); Class v. Norton, 505 F.2d 123 (2d Cir. 1974).

164. See text accompanying notes 105-18 supra. 
properly be viewed as flowing from the state's choice of conduct after the court's decree in the initial action. ${ }^{165}$ Alternatively, since the state had a clear opportunity to escape the sanction by honoring the prior decree, the state should not have a cognizable interest in claiming immunity, and whatever immunity the state previously enjoyed should be deemed waived by the state's actions. ${ }^{166}$ Under either view the conclusion is that the imposition of a conditional monetary award against a state as an enforcement tool is permissible under Ex parte Young and Edelman.

The use of Edelman's "ancillary effect" exception to justify a fee award in the initial proceeding, as in Jordan v. Fusari, ${ }^{107}$ is another matter. To be sure, a fee award is "forward-looking" since it encourages future plaintiffs to bring suit. But when the plaintiff's claims are settled in the present litigation, a fee award is not a "necessary result of attempts to gain coinpliance with a decree which by its terms was prospective in nature." A fee award in the initial proceeding inay indeed discourage the state from noncompliance with the court's order, but it is not essential. ${ }^{168}$ The same effect could be attained by conditioning the fee award on future noncompliance with the court's decree. ${ }^{169}$ It follows that a nonconditioned fee award is primiarily a compensatory device, and the focus is on restitution, not deterrence. Edelman, however, barred

165. Norton and Rodriguez differ in that in the latter case the compensatory award was expressly conditioned on noncompliance with the court's order. 496 F.2d at 1111-12. Arguably, the distinction should not be significant since in either case the defendant party is under court order and the consequence of noncompliance can be presumed to be known. But cf. Missouri v. Fiske, 290 U.S. 18, 28 (1933).

166. The situation is somewhat analogous to an individual's right of setoff against a state: where a state uses the courts to assert a claim against an individual, the state thereby waives its immunity to the extent that the individual may counterclaim against the state to defeat or diminish recovery. State of Alaska v. O/S Lynn Kendall, $310 \mathrm{~F}$. Supp. 433, 435 (D. Alaska 1970); accord, Board of Regents v. Dawes, 370 F. Supp. 1190 (D. Neb. 1974). Similarly, where the state uses extra-judicial means to nullify the individual's court-awarded relief, the state should be deemed to have waived its immunity to the extent of the individual's losses suffered thereby.

167. 496 F.2d 646 (2d Cir. 1974). In Jordan v. Fusari the state had waived (before Edelman v. Jordan) its eleventh amendment immunity by settling the issue of retroactive benefits. Although the settlement did not involve attorneys' fees, it did not appear that they were specifically excluded by the state. The district court ordered the payinent of fees froin the retroactive benefits on a common fund theory. On appeal, the United States, by invitation, argued that such use of funds under a federally assisted program was prohibited by federal law. Id. at 649 . The Second Circuit remanded for reconsideration on other equitable theories of fee awards, noting that the immunity has been waived, and, in any event, that payinent from state funds would be permissible under Edelman's "ancillary effects" exception. Id. at 651.

168. But cf. Edelman v. Jordan, 415 U.S. 651, $691-92$ (1974) (Marshall, J., dissenting).

169. See Rodriguez v. Swank, 496 F.2d 1110 (7th Cir. 1974). See also United States v. United Mine Workers, 330 U.S. 258, 303-05 (1947). 
the plaintiff's right to restitution from the state for past breaches of legal duty. ${ }^{170}$

A fee award does have an "ancillary effect" on the treasury, but the existence of a financial impact is not determinative of whether relief is permissible under Ex parte Young and Edelman. Rather, the "ancillary effect" under Ex parte Young and Edelman flows from the effect of the injunction and the state's efforts to conform its conduct with constitutional or federal standards. ${ }^{171}$ Where, as in Jordan v. Fusari, the fee award merely supplements the injunctive remedy, the effect of the fee award is clearly independent of any effects flowing from the mjunction.

\section{B. Assessment of Fees Against State Officials Individually}

The eleventh amendment does not extend constitutional immunity to state officials for their personal activities. Under the doctrine of Ex parte Young a state official is stripped of the eleventh amendment immunity from suit in federal court when his or her official conduct violates the Constitution. Thus, a state official acting under color of state law may be subject to personal liability under section 1983 of the Civil Rights Acts. ${ }^{12}$ Despite the existence of a federal cause of action, however, the official still may be protected by the common law doctrine of executive immunty from habilities arising from official conduct. ${ }^{173}$ Executive immunity, however, is neither absolute ${ }^{174}$ nor based on the same principle as common law sovereign immunity. While the latter results from the sovereign's prerogative of prescribing and limiting remedies against itself, the former focuses on the practical considerations of governance by imperfect people in an imperfect world. Thus, in Scheuer $v$. Rhodes, ${ }^{175}$ the Supreme Court intimated a necessity to find at least bad faith or good faith behef on unreasonable grounds on the part of the state official before a federal court could award compensatory

170. 415 U.S. $651,668-69,677$ (1974).

171. See text accompanying notes 69-125 supra.

172. 42 U.S.C. $\S 1983$ (1970) (derived from the Civil Rights Act of 1871, ch. 22, $\S 1,17$ Stat. 13). Section 1983 provides:

Every person who, under color of any statute, ordinance, regulation, custom, or usage, of any State or Territory, subjects, or causes to be subjected, any citizen of the Umited States or any other person within the jurisdiction thereof to the deprivation of any rights, privileges, or immunities secured by the Constitution and laws, shall be liable to the party injured in an action at law, suit in equity, or other proper proceeding for redress.

Federal court jurisdiction is conferred in 28 U.S.C. $\$ 1343(3)$ (1970).

173. Scheuer v. Rhodes, 416 U.S. 232 (1974). See also Wood v. Strickland, 95 S. Ct. 992 (1975) (school board immunity).

174. Scheuer v. Rhodes, 416 U.S. at 247. See also Wood v. Strickland, 95 S. Ct. at 998-1000.

175. 416 U.S. 232 (1974). Scheuer involved a suit against the Governor of Ohio, senior and subordinate officers of the state National Guard, and the president of a statecontrolled university. 
damages against him in an action for breach of civil rights. ${ }^{178}$ The existence of the immunity necessarily depends on the scope of the officer's discretion, the information before him, the amount of time available to come to a decision, and other factors which vary according to the circumstances attending his actions. Also to be considered is the fact that an assessment against the official individually, either in the form of attorneys' fees or compensatory damages, has traditionally been considered a punitive instrument. Thus, at least one recent Second Circuit case requires malice or clear abuse of discretion before a highly placed state official may be charged with attorneys' fees. ${ }^{177}$ This standard poses a greater barrier of executive immunity than the "bad faith" standard that generally is applicable to fee shifting, ${ }^{178}$ but it is sensible in terms of fairness to the individual defendant and as a safeguard against undue interference with the state's activities. Subjecting the official to greater liability may inhibit the incisive decisionmaking required of good government, for the official's discretion would be tainted by fear of personal liability. ${ }^{179}$ The Second Circuit's rule may lessen the probability of such difficulties since it seems likely that malice or clear abuse of discretion are more easily described than is "bad faith," and, presuniably, less likely to occur.

Consideration of the plaintiff's interests, on the other liand, suggests a more restricted immunity rule than that of the Second Circuit. For example, it seens appropriate to assess attorneys' fees against the

176. Id. at 247-48. In Wood v. Strickland, 95 S. Ct. 992 (1975), the Court construed section 1983 of Title 42 of the United States Code as extending qualified immunity to school board members sued for damages. The Court stated that the appropriate legal standard necessarily contains elements of both a subjeetive and objective test of good faith. Id. at 1000. The Court held that in the specific context of school discipline:

[A] school board member is not immune from liability for damages under $\S$ 1983 if he knew or reasonably should have known that the action he took within his sphere of official responsibility would violate the constitutional rights of the student affected, or if he took the action with the malicious intention to cause a deprivation of the constitutional rights or other imjury to the student. ...

Id. at 1001. In reference to the objective test, the Court inferred that the school board member would be lield to know "the student's clearly established constitutional rights." Id.

177. Class v. Norton, 505 F.2d 123, 127-28 (2d Cir. 1974) (state commissioner of velfare); cf. Gates v. Collier, 489 F.2d 298, 300-01 (1973), aff'd, 501 F.2d 1291 (5th Cir. 1974) (superintendent of state penitentiary); Hallmark Clinic v. North Carolina Dept. of Human Resources, 380 F. Supp. 1153, $1159-60$ (E.D.N.C. 1974) (licensing officials for abortion clinics). But cf. La Raza Umida v. Volpe, 57 F.R.D. 94, 101 (N.D. Cal. 1972), appeal dismissed, Civil No. 73-1145 (9th Cir. May 29, 1975) (nonappealable order) (chief highway engineer) (fee award against individual defendant justified on "private attorney general" theory even when reimbursement by the statute is unavailable).

178. Class v. Norton, 505 F.2d 123, 127 (2d Cir. 1974).

179. If the state has a reimbursenrent statute, however, a fee award against an 
individual officer when he or she has behaved "obdurately" in necessitating the initiation of an otherwise unnecessary lawsuit. This situation arguably would fall within the Second Circuit's rule, but it is not certain that this would always be the case. In addition, it might be argued that the "bad faith" standard is appropriate on the basis that public officials should exercise a higher standard of responsibility. The balance of interests may suggest an even more restricted immunity since equity favors the individual plaintiff who advances a significant public interest by successfully litigating a claim against the state. ${ }^{180}$ Accordingly, one commentator argues that the "bad faith" standard poses too great an obstacle for such a plaintiff. ${ }^{181}$

Obviously, there are significant interests on either side. It is also apparent that anything short of absolute executive immunity is likely to have sone impact on the state in that the possibility of personal liability lias sonie influence on the official's conduct. What is involved is a spectrum of possible effects, depending on the degree of potential liability. Some degree of liability is desirable because of the check on abuse of authority. On the other hand, if liability is imposed for something less than bad faith an inevitable result may be to force states to reiniburse officials who incur personal liabilities while acting in good faith $^{182}$ since states may not be able to function otherwise. Thus, although the plaintiff benefits under sucl an approach, the effect would be a judicial abrogation of the eleventh amendment.

As the standard for immunity approaches a middle ground such as "bad faith," the eleventlı amendment implications becoine less clear. Although the possibility of personal liability may still influence the officer's decisionmaking, the need for rennbursement by the state seenis less coinpelling. In addition, the argument that the state or its officials should not be permitted to act with impunity to plaintiff's detriment now carries inore force since there is an element of scienter. As the official's conduct becomes more egregious, the imposition of personal liability should be permissible irrespective of possible reimbursement of the official by the state. Certainly, as the conduct becomes tortious it seems

official in his individual capacity may have little impact on his conduct since the award in effect is against the state. See text accompanying notes 185-186 infra.

180. See notes 13-17 and accompanying text supra.

181. Comment, Attorneys' Fees and the Eleventh Amendment, supra note 155, at 100.

182. Id. at 100 \& n.85; cf. Dellinger, Of Rights and Remedies: The Constitution as a Sword, 85 HARv. L . Rev. 1532, 1556 (1972) ("It would . . . not be irresponsible for a [federal] court to restrict the immunity and good faith defenses available to the [federal] offieer while leaving to Congress the option of renoving the officer's liability by waiving the government's sovereign immunity."). Notions of federalism create additional difficulties in the context of suits against state officers. See text accompanying notes 267-69 infra. 
logical to disregard the state and to focus on the official's personal conduct. ${ }^{183}$ Apart from the equities involved, any possible interference with state functions under such circumstances should not be a sufficient state concern to warrant immunity.

A state statute which provides for reimbursement of habilities incurred by state officers ${ }^{184}$ presents a shightly different situation since the coercive effect of a personal judgment against the official is lessened. And arguably, such an award impacts only indirectly on the state treasury. ${ }^{185}$ However, it is clear that a monetary liability is thereby imposed on the state as a result of a federal court order. The appropriateness of this result is dependent upon the influence which the state statute has upon the court's decision to award fees. If the adoption of a restricted executive immunity rule is predicated upon the state's reimbursement of the official, then, in substance, the award is directed against the state, contrary to the Edelman rule. On the other hand, if the immunity rule would impose personal liability under given facts irrespective of a reimbursement statute, it is clear that the judgment is in fact directed at the official personally, and any subsequent reimbursement by the state does not lead to a result mconsistent with Edelman. One solution to this dilemma is to construe the reimbursement statute as a waiver of the state's eleventh amendment immunity. As lias been discussed, ${ }^{186}$ however, a state's consent to suit in its own courts does not constititute a waiver of the constitutional immunity to suit in federal courts absent a clear expression of intent. The state has the power to regulate the standard, be it willful imsconduct, bad faith, or negligence, by which its officials are held liable for attorneys' fees in state courts. But the state has no power to alter standards used by the federal courts. Furthermore, a state obviously does not impliedly waive immunity when it adopts or amends a reimbursement statute in response to the federal courts' awarding attorneys' fees against individual state officials according to a federal standard.

A reimbursement statute, then, has little independent significance in the determination of whether an assessment against the official in his or her individual capacity is inconsistent with the eleventh amendment. The nature of the official's conduct is the critical factor; the standard of

183. See Bivens v. Six Unknown Named Agents of Federal Bureau of Narcotics, 403 U.S. 388 (1971) (constitutionally-derived private right of action against federal agents for violation of fourth amendment); Monroe v. Pape, 365 U.S. 167 (1961) (cause of action under section 1983 against city police officers for constitutional violations).

184. See, e.g., CaL. Gov't CoDe $\$ \$ 825-25.6$ (West 1966); N.Y. Pub. Officers LAW \$ 17(1) (McKinney Supp. 1974).

185. Comment, Attorneys Fees and the Eleventh Amendment, supra note 155, at 98-99.

186. See text accompanying note 83 supra. 
conduct under the doctrine of executive immunity seems appropriate also as a guideline for determining immunity under the eleventh amendment.

\section{III}

\section{The Eleventh Amendment and Fee Awards Against STATES: Congressional Powers}

Preceeding sections of this Comment focused on attempts to reach a state or its officers under the doctrine of Ex parte Young. It is the most well developed of the eleventh amendment doctrines, and the decisional law on attorneys' fees has been limited to that context. As we have seen, this prevailing interpretation of the eleventh amendnent, as exemplified by Edelman, poses a significant bar to fee awards against states. Part III discusses several alternative theories focusing on congressional powers which may provide a basis for federal judicial power to assess attorneys' fees in private suits against a state. Congress' powers, of course, are limited by the Constitution. ${ }^{187}$ Thus, while the fourteenth amendnent's enforcenient clause is an important potential source of congressional fee shifting power, it may be subject to eleventh amendinent constraints. ${ }^{188}$ Although arguably the fourteenth amendment repealed pro tanto the eleventh amendment, ${ }^{180}$ at least with respect to federal claims, this theory has not been adopted by the Supreme Court, and this Comment will proceed on the assumption that such repeal has not occurred. Thus, any constitutional basis for fee shifting must be found within the labyrinth of eleventh amendnient doctrines or in an alternative interpretation of the eleventh amendinent.

\section{A. Congressional Power to Authorize Suits by the United States}

The common law doctrine of sovereign immunity, which developed in the context of suits against a sovereign by its subjects, does not immunize a state against suits by the federal government, another sovereign. Indeed, our constitutional schene of government requires

187. Oregon v. Mitchell, 400 U.S. 112, 128 (1970); McCulloch v. Maryland, 17 U.S. (4 Wheat.) 316,421 (1819).

188. Cf. Katzenbach v. Morgan, 384 U.S. 641, 650-51 (1966).

189. E.g., McCormack, Intergovernmental Immunity and the Eleventh Amendment, 51 N.C.L. REv. 485, 512 (1973) [hereinafter cited as MrCormack, Intergovernmental Immunity]; Note, Attorneys' Fees and the Eleventh Amendment, 88 HARv. L. REv. 1875, 1897-1901 (1975); Comment, Suing the State Under Title VII in the Face of the Eleventh Amendment, 1973 Wisc. L. Rev. 1099, 1115 (1973) [hereinafter cited as Comment, Suing the State Under Title VII]. Section 5 of the fourteenth amendment refers specifically to enforcement by Congress. Thus, the enforcenent clause may not empower the judiciary to imply a remedy or a private right of action against a state even if the fourteenth amendment limits the eleventh amendment's effect on constitutional claims. But see McCormack, Intergovernmental Immunity 512; Comment, Suing the State Under Title VII at 1115. 
that Congress have the power to authorize actions by the federal government in areas within congressional control. ${ }^{190}$ Moreover, since the eleventh amendment by its terms proscribes only suits by "citizens" it does not bar a suit against a state by federal authorities. Thus, there exists federal power to protect individuals from a state's violation of the Constitution or federal law. ${ }^{191}$

It might be argued that this federal power, in itself significant because it may ameliorate the need for a private right of action against the state, should also permit Congress to authorize a private riglit of action against a state in federal courts. Clearly, an action for a monetary judgment against a state by federal authorities on behalf of a private individual is tantamount to a private action against the state. One may also query whether the power to have federal authorities sue on behalf of private individuals should, in addition, imply a congressional power to authorize federal courts to award attorneys' fees in a private suit without the intervention of a federal official. If so, a distinction must be made between attorneys' fees and other monetary awards if the eleventh amendment is to remain effective as to the latter. Except where the fee award is used in a deterrent rather than compensatory mode, sucli a distinction is difficult to draw since both involve payments of state funds. It would therefore be difficult to escape the "general rule" recently affirmed by Edelman. ${ }^{192}$ Even if the award of attorneys' fees is distinguishable from other inonetary awards, however, adherence to a distinction between suits by the United States on behalf of a private individual and suits directly by the individual nonetheless may be required by the eleventh amendment. While the distinction may appear to be one of form rather than substance, it should be recognized that limiting suits which may be lieard by the courts to those brought by the federal government results in a far less drastic shift in the allocation of power between the state and federal governments than does a wholesale grant of power to federal courts. Given the present construction of the eleventh amendment, it would be improper for Congress to legislate around the amendment by granting private persons access to federal courts for suits against the states.

190. See United States v. California, 297 U.S. 175, 183-85 (1936); United States v. Texas, 143 U.S. 621 (1892).

191. This may be illustrated by reference to a specific statute. The Fair Labor Standards Act of 1938 provides:

When a written request is filed by any employee with the Secretary of Labor claiming unpaid minimum wages or unpaid overtime compensation ... the Secretary of Labor may bring an action in any court of competent jurisdiction to recover the amount of such claim . . . .

29 U.S.C. $\$ 216$ (c) (1970). Under the 1966 amendments some state employers fall within the Act's coverage. See 29 U.S.C. $\$ 203$ (d) (1970), amending 29 U.S.C. 203(d) (1964).

192. See text accompanying notes 69-96 supra. 


\section{B. An Alternative Interpretation of the Eleventh Amendment}

It is possible to interpret the eleventh amendinent in a manner that would not so completely bind the powers of Congress. Commentators have suggested that the eleventh amendinent should be limited to its historical context-forbidding suits in federal courts for debt claims against a state, based on state law $^{103}$ _and should not be read as limiting congressional or judicial powers in cases or controversies involving a federal question. ${ }^{104}$ It has also been argued that the fourteenth amendment effectively repealed that part of the eleventh amendment that limits judicial powers in federal question cases. ${ }^{105}$ Another commentator has suggested an Erie-type approach: state immunity should be respected in the context of state-created rights, but the federal forum should be open to entertain claims based on federally created rights. ${ }^{100}$ It has also been suggested that federal courts should decide whether to apply the eleventh amendment on the basis of a balancing of the federal and state interests involved in a particular case. ${ }^{107}$ Rather than pursue those arguments, the following discussion briefly explores another approach.

Under the prevailing view, the Hans decision ${ }^{108}$ extended the eleventh amendment to incorporate the states' common law immunity to suit by their own citizens. ${ }^{199}$ Thus, a state may not be sued in federal court without its consent. A state's common law immunity, however, does not preclude Congress from making federal regulations applicable to states and, as a concoimitant of that power, Congress may abrogate the state's immunity, at least as to suits in state courts. ${ }^{200}$ The underlying premise,

193. Comment, Monetary Remedies Against the State in Federal Question Cases, 68 Nw. U.L. REv. 544, 557-64 (1973) [hereinafter cited as Comment, Monetary Remedies Against the State].

194. Id. See also Note, A Practical View of the Eleventh Amendment-Lower Court Interpretations and the Supreme Court's Reaction, 61 GEo. L.J. 1473, 1498-99 (1973).

195. See note 189 and accompanying text supra.

196. Cullison, supra note 29 , at 19-24.

197. Note, Edelman v. Jordan: A New Stage in Eleventh Amendment Evolution, 50 Notre Dame L. 496, 505-06 (1975).

198. Hans v. Louisiana, 134 U.S. 1 (1889), discussed at text accompanying notes 57-59, supra.

199. Edelman v. Jordan, 415 U.S. 651 (1974); Employees v. Department of Pub. Health \& Welfare, 411 U.S. 279 (1973); Parden v. Terminal Ry., 377 U.S. 184 (1964). See generally, Comment, Private Suits Against States in the Federal Courts, 33 U. CHI. L. Rev. 331, 334-35 (1966) [hereinafter cited as Comment, Private Suits Against States]. The eleventh amendment incorporation view is not unanimously held, however. See note 58, supra.

200. See Edelman v. Jordan, 415 U.S. 651, 672 (1974); Employees v. Department of Pub. Health \& Welfare, 411 U.S. 279 (1973); id. at 288-90, 297-98 (Marshall, J., concurring); id. at 299-302 (Brennan, J., dissenting); Parden v. Terminal Ry., 377 U.S. $184,190-92$ (1964). 
of course, is that the states surrendered a portion of their sovereignty when they delegated certain powers to Congress. ${ }^{201}$

It would be consistent with this view of congressional powers to include within those powers the authority to abrogate immunity to suit in federal courts as well as state courts. That is, with the incorporation of common law sovereign immunity into the eleventh ainendment, also incorporated was Congress' power to abrogate the states' common law immunity in areas within congressional control. This interpretation should be distinguished from a general limitation of the eleventh amendment to nonfederal question cases. Under the latter view, federal judicial power over states would reach to the extent of federal question jurisdiction conferred by Congress, subject to whatever restrictions Congress may impose. Under the incorporation theory, federal judicial power over states would remain limited by the eleventh amendment unless Congress expressly creates a private right of action against states with respect to particular claims arising under federal law. This interpretation retains the state's immumity with respect to matters in which it is sovereign, but recognizes in Congress a power to override state sovereignty in matters in which Congress, under the supremacy clause, inust be sovereign. ${ }^{202}$

This construction entails a shift in power not from the states to federal courts, but fron1 the states to Congress. This interpretation, therefore, is consistent with the constitutional compromise in which the creation of lower federal courts was left to the discretion of Congress rather than mandated by the Constitution. ${ }^{203}$ In addition, this approach acknowledges the institutional structure established by the Constitution whereby the states are represented in the Congress but not in the federal courts. ${ }^{204}$ In view of the compromise in the establishment of the federal

201. Parden v. Terminal Ry., 377 U.S. 184, 191-92 (1964).

202. Justice Marshall has taken the position that constitutional sovereign immunity is implicit in article III, not the eleventh amendment. See Employees v. Department of Pub. Health \& Welfare, 411 U.S. 279, 291 (1973) (concurring opinion). If this is the case, one could argue, along lines analogous to those suggested in this section, that the limitation inherent in article III is not a total bar to federal judicial power in private suits against states, but rather a bar to the exercise of federal judicial power in the absence of specific congressional authorization. Under this approach, general federal question jurisdiction would not suffice; jurisdiction over a private suit against a state would not be available unless Congress creates a private right of action enforceable in federal courts.

203. See HART AND WeCHSLER, supra note 65, at 11-12.

204. See Mishkin, Some Further Last Words on Erie-The Thread, 87 HARv. L. REv. 1682, 1685 (1974). Another consideration is the concept of separation of powersthe creation of a private right of action against states involves policy issues which properly should be left to congressional resolution. $C f$. Alyeska Pipeline Service Co. v. The Wilderness Society, 95 S. Ct. 1612, 1625-28 (1975) (awards of attorneys' fees under the private attorney general rationale is not proper unless Congress has provided for fees). 
judiciary and the institutional structuring establislied by the Constitution, it is more appropriate to place in Congress' hands, rather than the Court's, the question whether the general federal judicial power may be invoked in private suits against states.

The suggested interpretation does not necessarily mean that states could be inade subject to suit under the thirteenth and fourteenth amendments' enforcement clauses. Congressional powers under these amendments did not exist when common law immunity was mcorporated into the eleventh amendment. Arguably, congressional power to abrogate sovereign immunity was included in the eleventh amendment only to the extent that such powers existed at the tinie of the incorporation. On the other hand, under the interpretation suggested here, the eleventh amendment limits not the power of Congress to act, but rather, the power of federal courts to act in the absence of express congressional authorization. Under this interpretation, it would be logically consistent to recognize congressional power to authorize suits against states in legislative fields later granted to Congress. Thus, enforcement powers under the Civil Rights Amendments were granted to Congress, not to the courts.

In sum, the suggested interpretation of the eleventh anendnent balances state and federal powers, recognizes in Congress the locus of federal lawmaking power, and heeds the apprehension with which states originally viewed the apparent federal judicial power over states on any claims otherwise cognizable under article III. In addition, the focus on congressional power is analogous to the Court's approach regarding the doctrine of implied waiver of eleventh annendment in1nuunity (discussed in the following section), and it is supported by the same policy considerations as form the basis for that doctrine. However, the suggested interpretation provides a more principled basis for the exercise of federal enforcement powers and allows the federal government greater flexibility in dealing with private grievances against states. $^{205}$

The interpretation suggested here is a compromise whicl removes the anomaly that under traditional eleventh amendment doctrine a state can sometimes, with impunity, disregard a superior constitutional or

205. The suggested interpretation is focused on suits against a state by citizens of the defendant state, which suits presently are barred by the Hans construction of the eleventh amendment. Thus, under the hiteral terms of the amendment, suits against a state by citizens of another state or of a foreign state would still be barred from federal courts. This is not a serious problem since suits by in-state plaintiffs predominate in number, and since the implied waiver doctrine would be available in the remaining suits which are explicitly proscribed by the eleventh amendment. The suggested interpretation conceivably could be extended to cover the latter category of suits, but this construction is more difficult in view of the literal terms of the amendment. 
federal law because it is not subject to private suit in federal court. Under the suggested interpretation, Congress may, if it deems it advisable, permit private enforcement in federal courts. Until the traditional interpretation of the eleventh amendment is modified, courts will be forced to seek other means, often fictional, to ameliorate the impact of the immunity.

\section{Congressional Power to Regulate State Conduct: Implied Waiver of Immunity}

\section{Analysis of the Doctrine}

State sovereignty doubtlessly was relinquisled to the extent that the Constitution granted specific powers to Congress. Therefore, states as well as individuals are subject to laws validly enacted by Congress. ${ }^{206}$ Valid enactment requires, of course, that other provisions of the Constitution not be violated. Therefore, Congress could authorize a private right of action on a federal claim against a state in federal court, except for the bar of the eleventh amendment as presently construed. While it may be permissible for Congress to condition the granting of a privilege on a waiver of constitutional rights so long as the condition is reasonable and necessary to the effectuation of the legislative purpose, ${ }^{207}$ in general the conditioning of a privilege on a waiver of constitutional rights runs counter to the doctrine of "unconstitutional conditions." 208 Nonetheless, in Parden v. Terminal Railway of the Alabama State Docks Department, ${ }^{209}$ Alabama was held amenable to private suit in federal court under the Federal Employers' Liability Act (FELA). ${ }^{210}$ After finding that Congress impliedly had intended to bring state-operated railroads within FELA's coverage, ${ }^{211}$ the Court held that Alabama, by its venture into the operation of an interstate railroad subsequent to the enactinent of FELA, ${ }^{212}$ had effectively consented to suit. Parden's novelty lies in its adoption of an implied waiver of eleventh amendment immunity. ${ }^{213}$ In contrast with the traditional state law standard under

206. Maryland v. Wirtz, 392 U.S. 183, $193-99$ (1968); United States v. California, 297 U.S. 175, 183-85 (1936).

207. See generally Note, Private Suits Against States 336.

208. See generally French, Unconstitutional Conditions: An Analysis, 50 GEo. L.J. 234 (1961); Hale, Unconstitutional Conditions and Constitutional Rights, 35 CoLUM. L. REv. 321 (1935); Merrill, Unconstitutional Conditions, 77 U. PA. L. REv. 879 (1929); Note, Unconstitutional Conditions, 73 HaRv. L. REv. 1595 (1960).

209. 377 U.S. 184 (1964).

210. 45 U.S.C. $\$ \$ 51$ et seq. (1970).

211. 377 U.S. at $187-90$.

212. Id. at 192-96.

213. See generally Comment, Implied Waiver of a State's Eleventh Amendment Immunity, 1974 DuKe L.J. 925 (1974) [hereinafter cited as Comment, Implied Waiver]; Comment, Monetary Remedies Against the State 547-48. 
which a state was not amenable to suit unless its consent was clearly expressed, ${ }^{214}$ Parden held, as a matter of federal law, that the state waived its immunity by engaging in activities within a federally regulated area. ${ }^{215}$ Read broadly, the Parden rationale imposed virtually no limitation on a finding of waiver attending state participation in a federally regulated activity so long as the requisite congressional intent to impose a condition on such state conduct is found. ${ }^{210}$ Accordingly, the Supreme Court subsequently has narrowly restricted this doctrine.

In Employees v. Department of Public Health \& Welfare ${ }^{217}$ the Court, in declining to find a waiver under the Fair Labor Standards Act (FLSA), ${ }^{218}$ held that Congress must express a clear intent to subject a state to suit in federal courts. ${ }^{219}$ Congressional intent, however, was only a partial basis for the holding that there had been no waiver. Although FLSA as originally enacted excluded the United States or any state or political subdivision of a state froin the Act's coverage, the 1966 amendments brought the defendant in Employees within FLSA's coverage. ${ }^{220}$ The Court's analysis focused in part on the fact that while the 1966 amendnients enlarged the definition of "employee" in section 3(d) of the Act, ${ }^{221}$ section $16(\mathrm{~b})$, which provides that "[a]ny employer who violates the provisions . . . shall be liable to the employee . . ." and that "[a]ction to recover such liability may be maintained in any court of competent jurisdiction . . .,"222 was not amended in 1966 specifically to allow a suit against state einployers in federal courts. ${ }^{223}$ As Justice Marshall noted in his concurring opinion, however, an amendment to section 16(b) appeared to be unnecessary to effect the desired extension of allowable actions to private suits against state employers. ${ }^{24}$ The Court's insistence on greater specificity therefore suggests that more was

214. See note 83 supra and accompanying text.

215. 377 U.S. at $192-96$.

216. One commentator has deemed the waiver theory a "convenient fiction enabling the Court to avoid a narrowing of the literal scope of the [eleventh] amendment." Comment, Monetary Remedies Against the State 547. The doctrine of Ex parte Young also has been called a fiction, but it has been an indispensable element of constitutional law. See text accompanying note 66 supra. Thus far, the doctrine of implied waiver has not attained such stature.

217. 411 U.S. 279 (1973).

218. 29 U.S.C. $\$ \$ 201$ et seq. (1970).

219. 411 U.S. at 284-87. Subsequently, in Edelman v. Jordan, 415 U.S. 651 (1974), the Supreme Court held the Parden waiver doctrine inapplicable because "congressional authorization to sue a class of defendants which hiterally includes States is wholly absent." Id. at 672.

220. See Maryland v. Wirtz, 392 U.S. 183 (1968).

221. See 29 U.S.C. \$ 203(d) (1970), amending 29 U.S.C. $\$ 203$ (d) (1964).

222. 29 U.S.C. $\& 216(\mathrm{~b})(1970)$.

223. 411 U.S. at 285 .

224. Id. at 289-90. 
involved than congressional intent. One possible concern is the kind of state conduct sufficient for a finding of waiver.

Assuming that the requisite congressional intent could be found in the legislative history of FLSA, a finding of implied waiver on the basis of the state's engagement in the regulated activities would seein unreasonable. Unlike Parden, where the state began its activities after the enactment of FELA, the state in Employees was already operating its facilities when FLSA was amended for the apparent purpose of bringing states within its coverage and permitting private suits in federal as well as state courts. As Justice Marshall stated in his concurring opinion, "[t]o suggest that the State had the choice of either ceasing operation of these vital public services or 'consenting' to federal suits suffices, I believe, to demonstrate that the State had no true choice at all and thereby that the State did not voluntarily consent to the exercise of federal jurisdiction ...."225 One could reasonably go further and assert that the timing of the federal legislation in relation to the state's initiation of the activity should not be a significant factor: it is as unreasonable to place conditions on the state's entry into the public health field as it is to place conditions on its continued operation in that vital field. Although the Court in Employees did not expressly consider what kind of conduct imphes a waiver, the problem received imphicit consideration since the potential hardship to the state was a significant factor in the Court's determination that Congress did not intend to subject the state to private suits in federal court. ${ }^{226}$ If the result so coerces the state as to require the clearest expression of congressional intent, a finding of an implied waiver under such circumstances would seem illogical. ${ }^{227}$

From the above disscussion, the implied waiver doctrine seems inappropriate for most state governmental functions. A waiver still could be inferred in the Parden situation where the state engages in a "proprietary" function rather than a necessary governmental function (assuming these can be meaningfully distinguished) and may realistically choose not to operate in the regulated area. ${ }^{228}$ Similarly, a waiver could be

225. Id. at 296.

226. Id. at 284-86.

227. See id. at 296 (Marshall, J., concurring).

228. At least one commentator noted that the Court, as in Parden and Employees, does not always clearly distinguish between common law sovereign immunity and eleventh amendment immunity. Accordingly, the commentator proposed a two-tier test. The first step is to determine whether Congress intended to remove the states' sovereign immunity. If such intent is found, the state is suable in state court. The second step is to determine whether a state has impliedly waived its eleventh amendment immunity. The latter determination requires an examination of factors such as the timing and nature of the state activity and the pervasiveness of federal regulation. See Comment, Implied Waiver, supra note 213 , at $958-68$. 
implied where the state cliooses to participate in a federal-state program in which Congress lias imposed conditions on incremental federal assistance. ${ }^{229}$ But if implied waiver requires a showing of voluntariness the doctrine has a rather narrow meaning.

An alternative implication of Employees is that the Court was concerned not so much with the nature of the state's activity or the circumstances of the waiver, but with the expression of congressional intent. The Court may have been setting a policy that congressional intent to create a private right of action against states in federal courts may not be implied, and that only express congressional action will suffice. Indeed, the Court noted that the statute did not expressly authorize private actions against state employers in federal courts. ${ }^{200}$ This policy is suggested also by Edelman v. Jordan, in which the Court declined to find a waiver because "the threshold fact of congressional authorization to sue a class of defendants which literally includes States is wholly absent."231 If this is the policy, the Court's discretion to imply a waiver is further restricted.

This limitation on the doctrine is appropriate in light of Congress' preeminent role as the federal lawmaking institution. ${ }^{232}$ The question of whether states, as a matter of policy, should be subject to private suit under a given statutory scheme involves sensitive issues which are best left to congressional resolution in the first instance. Of course, it is properly a judicial function to determine whether Congress' decision has constitutionally permissible application in a given case.

The selection of the standard to be applied by the courts in determining waiver is a complex problem and has yet to be resolved. The doctrine of implied waiver logically should be quite narrow since true waiver requires an element of voluntarimess. In addition, the traditional and prevailing interpretation of the eleventh amendment suggests that nothing short of a state's actual consent will suffice. On the other

This proposed test poses some conceptual difficulties since it slights the question of congressional intent to make federal courts accessible. While congressional intent to abrogate common law immumity might suffice, the question is not only whether a state should be suable, but in whose court. An "implied" waiver as to the eleventh amendment immunity obviously will shift power from the state to the federal courts-an issue to which the states are not insensitive. Congress thus should have a significant voice in the determination. See further text accompanying notes 230-232 and 253-284 infra.

229. See Justice Marshall's dissent in Edelinan v. Jordan, 415 U.S. 651, 688 (1974), regarding a suit for retroactive benefits under Aid to the Aged, Bhind, or Disabled (AABD), a categorical assistance program under the Social Security Act, 42 U.S.C. $\$ \S$ 1382-85 (Supp. V 1964). (Effective January 1, 1974 this AABD program was replaced by a similar program. See 42 U.S.C. $\$ \S 801-05$ (Supp. II 1970).)

230. See text accompanying notes 221-223 supra.

231. 415 U.S. 651,672 (1974).

232. See text accompanying notes $259-67$ infra. 
hand, policy considerations flowing from the illogic of the eleventh amendment suggest a more liberal construction of the implied waiver doctrine. At present it provides the only avenue of affording a panoply of judicial remedies directly against a state. In the interests of preserving the legitimacy of the implied waiver doctrine, some limitation seems both desirable and necessary. Accordingly, it is not unreasonable to require a threshold showing of at least a clear congressional intent, if not express action, to authorize suits against states under the particular statutory scheme. Given this, the courts should be liberal in determining what conduct suffices for an inference of waiver. The fact that Congress has acted suggests that state activities falling within the purview of the statute should be deemed sufficient to constitute waiver, and the courts should give due consideration to Congress' decision.

\section{The Waiver Doctrine and Attorneys' Fees}

As discussed above, waiver of eleventh amendment immunity depends on the legislative intent, either express or implied, behind the statute at issue and on inferences from the state's conduct. If the legislative intent must be implied, guesswork is required. The ambiguities are perhaps amplified in an analysis of the nore particular issue of waiver of immunity to attorneys' fees. The following discussion illustrates soine of the difficulties.

When a federal statute expressly provides for an award of attorneys' fees against a state, congressional intent is clear, and the only 1najor difficulty is finding a basis for a waiver of immunity in the state's conduct. Without waiver, the statute cannot be effective, for, as discussed above, ${ }^{233}$ congressional power to subject states to private suit in federal court is limited by the eleventh amendinent, as traditionally interpreted. The Emergency School Aid Act of $1972^{234}$ is an example of a statute expressly providing for an award of attorneys' fees. Section 718 of the Act provides:

Upon the entry of a final order by a court of the United States against ... a State (or any agency thereof), or the United States (or any agency thereof), for failure to comply with any provision of this chapter or for discrimination on the basis of race, color, or national origin in violation of title VI of the Civil Rights Act of 1964, or the fourteenth amendment to the Constitution . . . as they pertain to elementary and secondary education, the court, in its discretion, upon a finding that the proceedings were necessary to bring about compliance, may allow the prevailing party, other than the United States, a reasonable attorney's fee as part of the costs. ${ }^{235}$

233. See text accompanying notes 187-89 supra.

234. 20 U.S.C. $\S \S 1601$ et seq. (1972).

235. 20 U.S.C.A. $\$ 1617$ (Supp. 1973) (section 718 of the Emergency School Aid Act). 
When a state or agency chooses to accept federal funds for elementary or secondary education, a waiver of immunity, given the explicitness of section 718, is not difficult to infer. Section 718, lowever, is an omnibus provision which does not itself create a private riglit of action against a state. Suits invoking section 718 against state or local officials ${ }^{236}$ typical1y are brought under section 1983 of the Civil Rights Acts, ${ }^{237}$ which does not specifically allow private actions against a state. However, some section 1983 actions are, in effect, directed against a state, ${ }^{238}$ and under such circumstances section 718 seems sufficiently explicit to find a waiver of immunity from attorneys' fees. But the state presumably would retain its immunity in other respects.

Another type of fee-authorizing statute provides more explicitly for a private right of action against a state in federal court. Again, the problem is to determine what state conduct constitutes a waivcr. Under Title VII of the Civil Rights Act of $1964,{ }^{239}$ as anended by the Equal Employment Opportunities Act of 1972, a private right of action against a governmental entity is permitted by section $2000 \mathrm{e}-5(\mathrm{f})(1)$, and the prevailing party may recover attorneys' fees under section $2000 \mathrm{e}-5(\mathrm{k})$ of Title 42 of the Umited States Code. Given the fair assumption that state activities within the coverage of this statute constitute important state governmental functions, it bends credulity to infer a waiver solely from the state's participation in the underlying activity unless the state uses supplemental federal funds.

A more persuasive basis for a waiver of imnumity is the statutory scheme for enforcement by private individuals. Under the Equal Employment Opportumities Act, the Equal Employment Opportunity Commission has primary responsibility for enforcement; a private right of action arises only after the Comnission fails to achieve a settlement and declines to bring suit. ${ }^{240}$ Given the express statutory authorization of attorneys' fees and private suit, waiver of immunity reasonably may be inferred when a state unreasonably fails to settle after intervention by the federal agency. ${ }^{241}$ Waiver, then, results not from engaging in the underlying activity, nor from discriminating in violation of the Act, but

236. See, e.g., Bradley v. School Board, 416 U.S. 696 (1974); Medley v. School Board, 482 F.2d 1061 (4th Cir. 1973), cert. denied, 414 U.S. 1172 (1974). These cases against local officials and governmental entities did not consider whether a state may be compelled to pay attorneys' fees.

237. 42 U.S.C. $\$ 1983$ (1970) (derived from the Civil Rights Act of 1871, ch. 22, $\S 1,17$ Stat. 13).

238. For example, an action against an official is, in effect, against the state where the official lacks personal culpability.

239. 42 U.S.C. $\$ \$ 2000$ et seq. (Supp. 1972).

240. 42 U.S.C. $\$ 2000 \mathrm{e}-5(\mathrm{f})(1)$ (Supp. 1972).

241. See Class v. Norton, 505 F.2d 123 (2d Cir. 1974); Rodriguez v. Swank, 496 F.2d 1110 (7th Cir. 1974). 
from unreasonably necessitating the initiation of a private suit. This is the analog of the "obdurate behavior" rationale for assessing fees against a state official. ${ }^{242}$

Another type of fee-authorizing statute provides for a private right of action and fees, but does not specifically authorize suits against states. An example is the public accommodations section of Title II of the Civil Rights Act of 1964.243 While the statute covers facilities "supported by State action," 244 the enforcement section refers only to suits against persons, not states. ${ }^{245}$ Thus, applicability of the waiver doctrine turns largely on statutory construction. Since the waiver doctrine requires a clear expression of congressional intent, if not express authorization to sue states, the doctrine seems inappropriate for this type of statute unless there is strong legislative history which suggests that states were to be included in the class of defendants.

The waiver problein is inost difficult when the statute refers neither to states nor to attorneys' fees. Such a case is presented in inost 1983 actions. ${ }^{240}$ In comparison with statutory provisions which explicitly proscribe state conduct, section 1983 requires a broader reading of the implied waiver doctrine to find a limited waiver of immunity from attorneys' fees. ${ }^{247}$ The obvious difficulty is that seetion 1983 by its terms applies only to a "person" and a state is not a "person" within the nieaning of the statute. ${ }^{248}$ Yet, section 1983 clearly was directed to the prohibitions of the fourteenth anendment, which refers specifically to states, ${ }^{249}$ and the Supreme Court has stated that "[t]he very purpose of $\S 1983$ was to interpose the federal courts between the States and the people, as guardians of people's federal rights-to protect the people from unconstitutional action under color of state law, "whether that

242. See note 11 supra.

243. 42 U.S.C. \& 2000a et seq. (1970).

244. Id. $\$ 2000 \mathrm{a}(\mathrm{b})$.

245. See id. $\$ 2000 \mathrm{a}-3$ (a).

246. See 42 U.S.C. $\$ 1983$ (1970).

247. See Edelman v. Jordan, 415 U.S. 651, 675-77 (1974).

248. Bennett v. California, 406 F.2d 36, 39 (9th Cir.), cert. denied, 394 U.S. 966 (1969). Cf. Moor v. County of Alameda, 411 U.S. 693, 698-710 (1973) (county not liable under sections 1983 and 1988 of the Civil Rights Act); Monroe v. Pape, 365 U.S. 167, 187-91 (1961) (municipality not a "person" within the meaning of section 1983 of the Civil Rights Act, R.S. 1979).

249. The bill creating the predecessor to section 1983 was labeled as one "To enforce the provisions of the fourteenth amendment to the Constitution of the United States." H.R. ReP. No. 320, 42d Cong., 1st Sess. (1871). One explanation for the limitation of section 1983 to "persons," aside from the obvious imphications of the eleventh amendment, is that a major concern which pronupted the enactinent of the Civil Rights Act was the widespread violence of individuals and the concomitant circumstance of local and state maction. Shapo, Constitutional Tort: Monroe y. Pape and the Frontiers Beyond, 60 Nw. U.L. REv. 277, 279-80 (1965). 
action be executive, legislative, or judicial." "250 It is equally clear that many section 1983 suits against state officials are, in substance, against the state itself, and the only effective limitation is on remedies. In view of section 1983's manifest purpose of protccting individuals from unlawful state action, it reasonably can be inferred that Congress intended states to be responsible for the actions of officers done on behalf of the state. ${ }^{251}$ Indeed, Ex parte Young recognizes that some remedy against the state inust be available.

Yet, the relief available under Ex parte Young-injunctive and declaratory-may not be sufficient. Injunctive relief traditionally is not available unless an adequate remedy at law does not exist, and irreparable injury threatens. State immunity to other remedies provides a compelling need for imjunctive relief in federal court. But more may be needed. Section 1983 actions against state officials typically involve welfare, prisoners' rights, desegregation and other controversies where plaintiffs are highly unlikely to be able to finance their own lawsuits. Given the strong policy of providing a federal forum, where needed, and the limitation on monetary remedies against states, attorneys' fees arguably are a necessary supplemental remedy.

Where the state official is protected by the executive immunity doctrine from personal liability, and absent state consent to the assessment of attorneys' fees, the implied waiver doctrine affords practically the only means of fee shifting in a section 1983 action. But application of the implied waiver doctrine in this context takes it to its logical bounds. Not only must it be inferred that the legislative intent was to make states as well as state officials directly liable, the wide scope of contexts in which a section 1983 action may be brought increases the difficulty of determining what kinds of conduct imply a waiver since the statute itself gives no clue. Because limited application of the implied waiver doctrine seems essential to its preservation, application of the doctrine in this context would require the drawing of a principled line applicable in other contexts. A waiver for attorneys' fees could be distinguished from other situations by focusing on the role that fee shifting would play in facilitating vital access to courts, since Ex parte Young cannot be fully effective unless putative plaintiffs are financially able to have their clains heard. This distinction separates attorneys' fees from other monetary claims, but does not solve the problem of inferring waiver from conduct. Under such circumstances, fee shifting necessarily requires the court to judicially legislate fee awards after making policy judgments concerning the circunistances under which exceptions to the

250. Mitchum v. Foster, 407 U.S. 225, 242 (1972), quoting Ex parte Virginia, 100 U.S. 339, 346 (1879). See also Monroe v. Pape, 365 U.S. 167, 173-74 (1961).

251. See, e.g., Brandenburger v. Thompson, 494 F.2d 885 (9th Cir. 1974). 
general rule against nonstatutory fee awards should be permitted. Thus, although the waiver doctrine arguably could be used to permit fee shifting, the narrow construction of the waiver doctrine suggested by Supreme Court opinions and the Court's recent disapprobation of the private attorney general rationale for awarding fees ${ }^{252}$ make it difficult for the inplied waiver doctrine to be used in this context.

IV

\section{Attorneys' FeEs and Judicial Implication of Remedies}

An award of attorneys' fees in the absence of express congressional authorization involves some degree of judicial lawmaking. Although the general American rule bars nonstatutory fee shifting, federal courts have used their equitable power, derived from the Englisli Court of Chancery, ${ }^{253}$ to award attorneys' fees "when the interests of justice so require." 254 But equity, despite its breadth, does not provide a complete answer in determining whether the federal judiciary appropriately may use its lawmaking powers to infer an attorneys' fee remedy in a private suit against a state or state officials. Preceding sections of this Comment focused on the eleventh amendinent limitations on federal power-both judicial and legislative. These limitations suggest that judicial power to assess fees basically is limited to personal judgments against state officials under the doctrine of Ex parte Young unless the state has expressly consented to suit or impliedly has waived its eleventh amendment immunity. Inevitably, there are areas of uncertainty. For example, the extent of fee shifting under Ex parte Young depends on the degree to which the indirect impact on the state may be disregarded. In addition, application of the implied waiver doctrine at times may be impermissibly coercive and therefore inconsistent with the eleventh amendment. Moreover, the scope of the intplied waiver doctrine itself depends on whether applicability of the doctrine is predicated on express congressional intent or whether the latter also may be implied. The further development and refinement of these doctrines involve not only eleventh amendment jurisdictional restraints, but also sensitive issues of federal-state relationships and policy determinations to support exceptions to the general rule against nonstatutory fee shifting. The question thus is not only one of judicial power, but also one of the federal judiciary's lawmaking competence vis-à-vis that of Congress.

252. Alyeska Pipeline Service Co. v. The Wilderness Society, 95 S. Ct. 1612 (1975). See the discussion at notes 14-17 and accompanying text supra, and also text accompanying notes 263-64 infra.

253. Sprague v. Ticonic Bank, 307 U.S. 161, 164-66 (1939). It should be noted that in England the King was not required to pay costs. Fairmont Creamery Co. v. Minnesota, 275 U.S. 70 (1927).

254. Hall v. Cole, 412 U.S. 1, 5 (1973). 
The federal judiciary, to be sure, has the power to create remedies $^{255}$ and to infer private rights of action for violation of federal law ${ }^{250}$ and the Constitution, ${ }^{257}$ even in the absence of specific legislative authorization. ${ }^{258}$ The basic constitutional grant of lawmaking powers within the federal system, however, went to Congress; ${ }^{260}$ the federal judiciary plays only a secondary role. This allocation of lawmaking powers results in part from the separation of powers doctrine and from the principle that policy should be made primarily by a pohtically responsible body. ${ }^{260}$ This aspect of lawmaking competence is highly important to the present discussion simce fee shifting, perhaps particularly against a state or its officials, rests ultimately on notions of public policy. For example, the "private attorney general" rationale for fee shifting was based on the plaintiff's furtherance of public policy and his vimdication of public rights. ${ }^{201} \mathrm{~A}$ particular concern with judicial implication of attorneys' fees arises froin the judiciary's selecting among federal rights and plaintiffs those which most deserve the additional remedy of fee shifting. Decisions of this type go beyond the balancing of equities involved in traditional fee shifting between private litigants. As one

255. For example, the federal judiciary formulated the exclusionary rule in criminal prosecutions without specific legislation, but pursuant only to the general grant of jurisdiction to the federal courts by the Constitution and Congress. Katz, The Jurisprudence of Remedies: Constitutional Legality and the Law of Torts in Bell v. Hood, 117 U. PA. L. REv. 1, 42-43 (1968) [hereinafter cited as Katz, Jurisprudence of Remedies]. It is noteworthy that the injunctive remedy against governmental actions, the writ of habeas corpus and the exclusionary rule, are defensive, prohibitive remedies. An award of attorneys' fees, in contrast, may be used as an offensive remedy.

256. J.I. Case Co. v. Borak, 377 U.S. 426 (1964). See generally Note, Implying Civil Remedies From Federal Regulatory Statutes, 77 HARv. L. REv. 285 (1963) [hereinafter cited as Note, Implying Civil Remedies].

257. Bivens v. Six Unknown Named Agents of Federal Bureau of Narcotics, 403 U.S. 388 (1971).

258. See generally, Hill, Constitutional Remedies, 69 Colum. L. Rev. 1109, 1158 (1969) ("[C]ourts enjoying general jurisdictional and remedial authority adequate to the protection of constitutional rights do not need, additionally, specific authorization to that end."); Dellinger, Of Rights and Remedies: The Constitution as a Sword, 85 HARv. L. Rev. 1532, 1540-42 (1972) [heremafter cited as Delinger, Rights and Remedies]; Note, The Competence of Federal Courts to Formulate Rules of Decision, 77 HARv. L. REv. 1084, 1089 (1964) [hereinafter cited as Note, Rules of Decision].

259. E.g., U.S. CoNST. art. I, § 8; id. amend. XIII, $\S 2 ; i d$. amend. XIV, § 5; id. amend. $\mathrm{XV}, \S 2$.

260. Mishkin, The Variousness of "Federal Law": Competence and Discretion in the Choice of National and State Rules for Decision, 105 U. PA. L. REv. 797, 800 \& n.12 (1957) [heremafter cited as Mishkin, Variousness of Federal Law]; Cox, The Supreme Court 1965 Term, Foreword: Constitutional Adjudication and the Promotion of Human Rights, 80 Hurv. L. Rev. 91, 119 (1966) [hereinafter cited as Cox, Constitutional Adjudication]; Note, Rules of Decision at 1085.

261. E.g., Brandenburger v. Thompson, 494 F.2d 884, 889 (9th Cir. 1974); La Raza Unida v. Volpe, 57 F.R.D. 94, 96 (N.D. Cal. 1972), appeal dismissed, Civil No. 73-1145 (9th Cir. May 29, 1975) (non-appealable order). 
commentator notes, "[t]he idea of federal courts doing anything which resembles making a rank ordering of federal rights is open to fundamental question."262 Congress is better structured to weigh the competing interests and to formulate federal policy. Thus, in Alyeska Pipeline Service Co. v. The Wilderness Society, ${ }^{203}$ the Supreme Court held that nonstatutory attorneys' fee awards under the private attorney general rationale were an inappropriate invasion of the legislature's province. ${ }^{264}$ Although the private attorney general doctrine is now vitiated, the same considerations of separation of power clearly are applicable to the implied waiver doctrine $e^{265}$ and the common benefit doctrine ${ }^{266}$ since both situations may involve the judicial implication of a remedy when congressional guidance is not clear.

Congress' preeminent role in federal lawmaking results also from considerations of federalism since the states wield significant influence in the federal political process. Therefore, decisions made by this body should tend to ensure a proper balance in federal-state relationships. ${ }^{267}$ The balance of federal and state powers involves not only substantive law, but also the means of implementation. Although the congressional policy underlying a substantive federal claim may be easy to identify, in general "choosing the means of achieving permissible objectives is a legislative function." ${ }^{268}$ This may be particularly true where, as in the case of fee shifting, the claimed remedy is offensive rather than passive. ${ }^{269}$ While an action for attorneys' fees may be viewed as only the remedial implementation of a substantive rule, as a monetary judgment against the state a fee award takes on a substantive character as an affirmative remedy against the state. The potential effect on the fiscal affairs of the state is not insignificant; a fee-shifting policy that requires payment by the state constitutes, in substance, a judicially created state legal aid systen. If, alternatively, fees are assessed against a state officer in his individual capacity, serious questions are raised

262. Note, Limiting the Section 1983 Action in the Wake of Monroe v. Pape, 82 Harv. L. REv. 1486, $1492 \mathrm{n.40}$ (1969) [hereinafter cited as Note, Wake of Monroe v. Pape.

263. 95 S. Ct. 1612 (1975).

264. Id, at $1627-28$.

265. The implied waiver doctrine and its applicability to fee awards are discussed at text accompanying notes 206-252 supra.

266. See notes 12,17 supra.

267. Mishkin, Some Further Last Words on Erie, supra note 204, at 1685; Mishkin, Variousness of Federal Law, supra note 260, at 800 n.12; Hart, State and Federal Law, supra note 65; Note, Rules of Decision, supra note 258, at 1085; see Wechsler, The Political Safeguards of Federalism: The Role of the State in the Composition and Selection of the National Government, 54 COLUM. L. REV. 543 (1954).

268. Cox, Constitutional Adjudication, supra note 260, at 110.

269. See Hart, State and Federal Law, supra note 65, at 523. 
of undue interference with officials acting in good faith. ${ }^{270}$ Although the common law doctrine of qualified executive immunity protects against the latter problem, difficulties in defining a standard of immunity and applying it to particular facts leaves open the possibility of sone interference. On the other hand, the assessment of attorneys' fees as a punitive nueasure is a more proper judicial function, and the Supreme Court has recognized general inherent power to assess fees on this basis while disapproving the private attorney general rationale. ${ }^{271}$ Thus, as the fee award loses its punitive character as an assessment directed to the state official in his or her individual capacity, and begins to impact more directly on the state, the judicial implication of the fee shifting remedy becomes less tenable, and more congressional guidance is desirable.

Fee shifting may additionally concern the relative roles of the federal and state judiciaries smce the possibility of a fee award in fcderal court creates an additional mcentive for suits in federal courts. Although the plaintiff may also prefer the federal forum for other reasons, the availability of fee shifting makes it easier to sue and thus tacitly encourages suits against states. The issue, of course, is not whether plaintiffs should be aided in the vindication of federal rights, but rather who should set the policies. As discussed above, because the states are represented in Congress, this body is better qualified to maintain the proper balance in federal-state relationships. For this reason, Congress would appear to be the appropriate body to determine whether the incentive to sue in federal court should be available.

It is arguable, then, on several grounds, that Congress is generally the preferable branch of government to decide whether federal courts should grant the shifting of attorneys' fees. It is significant that Congress is not unaware of the fee shifting issue and has authorized fee awards in conjunction with certain claims ${ }^{272}$ and specifically against

270. These problems may be alleviated in part by adopting the English procedure of awarding "costs" (to use the English terminology) to the prevailing party rather than solely to the prevailing plaintiff. See generally, C. McCormick, HANDBOor oN THE LAw of DAMAges $\$ 60$ (1935); Goodhart, Costs, 38 Yale L.J. 849 (1929). The American federal equity practice has assessed fees against plaintiffs who have brouglit "vexatious" suits. Guardian Trust Co. v. Kansas City S. Ry., 28 F.2d 233 (8th Cir. 1928), rev'd on other grounds, 281 U.S. 1 (1930); Gazan v. Vadsco Sales Corp., 6 F. Supp. 568 (E.D.N.Y. 1934). This procedure discourages nonmeritorious lawsuits, but also poses a danger of discouraging suits that perhaps should be brouglit. In view of this possibility a more appropriate procedure may be to assess attorneys' fees against the unsuccessful plaintiff when the action was plaimly frivolous; a stricter standard may create more of a burden than the plaintiff faces in the absence of any attorneys' fees.

271. Alyeska Pipeline Service Co. v. The Wilderness Society, 95 S.Ct. 1612 (1975).

272. E.g., Title II, Civil Rights Act of 1964, 42 U.S.C. $\S 2000 \mathrm{a}-3$ (b) (1970) (discrimination in public accommodations). 
states. ${ }^{278}$ Federally funded legal aid also has not escaped congressional scrutiny. Thus, the situation generally differs from that of Bivens $v$. Six Unknown Named Agents of Federal Bureau of Narcotics, ${ }^{274}$ a suit against federal agents, where congressional inaction militated toward a judicially created federal cause of action. Moreover, Congress is certainly aware of the eleventh anendment problems and has been careful at times to avoid a direct confrontation. ${ }^{275}$ It is appropriate for the courts to follow this example. Also, Congress has been reluctant to waive the sovereign immunity of the United States. Congress has authorized the assessnient of costs against the United States, ${ }^{276}$ but courts nay assess attorneys' fees against the federal government only when expressly consented to. ${ }^{277}$ Arguably, the federal judiciary should exercise greater restraint in legislating a remedy against a state than against the federal government. In addition, although the English law is the source of the federal judiciary's inherent fee shifting powers, the immunity of the federal government is consistent with the English law, which prohibits the assessment of costs against an officer even when the latter sues on behalf of the Crown. ${ }^{278}$

On the other hand, it can be argued that the judiciary in allowing attorneys' fees is acting within its inherent powers, if not duty, in

273. E.g., Emergency School Aid Act, 20 U.S.C. $\$ 1617$ (Supp. II 1972), quoted at text accompanying note 235 supra. Section 1617 does not necessarily authorize an award of attorneys' fees in a private suit against a state official since the section presumes a final judgment against the state, which will not occur in a private suit in federal court unless the state has waived its eleventh amendment immunity.

274. 403 U.S. 388 (1971). Bivens is discussed briefly at note 67 supra.

275. See, e.g., Clean Air Act \& 12(a), 42 U.S.C. \& 1857h-2(a)(1) (1970), which provides in pertinent part:

(a) [A]ny person may commence a civil action on his own behalf-

(1) against any person (including (i) the United States, and (ii) any other governmental instrumentality or agency to the extent permitted by the Eleventh Amendineut to the Constitution) who is alleged to be in violation of (A) an emission standard or limitation under this chapter or (B) an order issued by the Administrator or a State with respect to such standard or limitation . . . .

276. 28 U.S.C. $\$ 1920$ (1970); 28 U.S.C. $\& 2412$ (1970). The assessment of court costs against the United States was authorized by Pub. L. No. 89-507 (July 18, 1966), amending 28 U.S.C. $\$ 2412$ (1964). The prior freedom from costs was, not surprisingly, an outgrowth of sovereign immunity. Jacoby, The 89 th Congress and Government Litigation, 67 CoLUM. L. Rev. 1212, 1234 (1967).

277. 28 U.S.C. \& 2412 (1970); Wilderness Society v. Morton, 495 F.2d 1026, 1036 (D.C. Cir. 1974), rev'd on other grounds sub nom., Alyeska Service Co. v. The Wilderness Society, 95 S.Ct. 1612 (1975). The Umited States has consented to the assessment of attorneys' fees against itself under some statutes. E.g., Equal Employment Opportumities Act, Title VII, Civil Rights Act of 1964, 42 U.S.C. $\$ 2000 \mathrm{e}-5(\mathrm{k})$ (1970); Emergency School Aid Act, 20 U.S.C. $\$ 1617$ (Supp. II 1972).

278. 16 The ENGLish and EMpIRe Digest 546, IT 3874, 3878 (1961). Cf. Fairmont Creamery Co. v. Minnesota, 275 U.S. 70 (1927). Fairness dictated that an officer of the Crown could not claim costs froin an unsuccessful plaintiff. J. ADAMs, The Doctrine of EQUTTY 390 (8th ed. 1890). 
providing a supplemental remedy. An essential function of the federal courts is 'to declare, as a matter of common law or 'judicial legislation,' rules which may be necessary to fill in interstitially or otherwise effectuate the statutory patterns enacted in the large by Congress."270 In $E x$ parte Young the Supreme Court perhaps went further and inferred a federal cause of action against state officers in order to effectuate the mandate of the fourteenth ainendment and, more recently, the Court created a private right of action for damages against a federal officer for a violation of the fourth alnendinent of the Constitution. ${ }^{280}$ The standard which justifies judicial legislation generally is one of "necessity" or "appropriateness."281 Fee shifting in federal question suits against a state arguably meets these criteria since it facilitates access to a federal forum. In addition, the remote possibility of obtaining other compensatory relief may prove to be a disincentive to plaintiffs who have substantial federal claims against the state. Fimally, the United States Attorney General's office and other federal agencies may be unable adequately to handle all the suits that should be brought against state officials which ordinarily warrant fee shifting. ${ }^{282}$ Indeed, one court has deemed an award of attorneys" fees to be "essential."."28

Obviously, there are strong arguments on both sides. The equities certainly are on the side of the indigent plaintiff. On the other hand, the determination of whether an award of attorneys' fees is essential is in large part a policy matter which should take into consideration other alternatives. Congress is likely to have a wider range of alternatives available, and is better able to weigh the competing interests. The courts have the power to award nonstatutory fees, subject to eleventh amendment limitations, but a consideration of the institutionalized structuring

279. Mishkin, Variousness of Federal Law, supra note 260, at 800 . See also Note, Implying Civil Remedies, supra note 256, at 291, and the illuminating concurring opinion by Justice Harlan in Bivens v. Six Unknown Named Agents of Federal Bureau of Narcotics, 403 U.S. 388, 398-411 (1971).

280. Bivens v. Six Unknown Named Agents of Federal Bureau of Narcotics, 403 U.S. 388 (1971). The question was reserved in Bell v. Hood, 327 U.S. 678 (1946). The time required to answer suggests a reluctance to judicially legislate in an area that arguably is more appropriate for congressional action.

281. Bivens v. Six Unknown Named Agents of Federal Bureau of Narcotics, 403 U.S. 388, 406-07 (1971) (Harlan, J., concurring); J.I. Case Co. v. Borak, 377 U.S. 426. 432-33 (1964). See also Katz, Jurisprudence of Remedies, supra note 255, at 33:

The decision in J.I. Case is a function of the presence of four dependent variables: (a) the protective purposes of the statute; (b) the absence of contrary legislative expression; (c) the grant of general jurisdiction to the federal courts; and (d) the inherent power of the federal courts to adjust reinedies to meet ends.

282. See Note, Private Attorney General, supra note 11, at 733.

283. Sims v. Amos, 340 F. Supp. 691, 695 (M.D. Ala. 1972), aff'd mem. 409 U.S. 942 (1972) (reapportionment). On the significance of the affirmance to the attorneys' fee issue, see note 131 and accompanying text supra. 
of the federal government and its relationship to the states, and the policy issues attending fee shifting against states, suggest moderation in judicial action, at least while the issue is before the legislators' attention.

\section{CONCLUSION}

There are significant, perhaps compelling, arguments in favor of fee shifting in private suits against state officials due to the eleventh amendment limitation on the judicial power of federal courts to award fees and other judgments agaimst the states themselves. Since the eleventh amendinent substantially bars a federal court from ordering specific relief that works against the state, a successful plamtiff in all probability will be limited to an injunction agamst the injurious conduct and a declaration of rights. Any prospective pecumiary benefits are likely to be small in comparison to the costs of litigation. Thus the limitation on relief acts as a significant financial barrier to putative plamtiffs who typically are ill-situated to finance their own lawsuits. In addition, the state defendants commonly are defended by the state attorney general who otherwise might be expected to defend plaintiffs' rights. ${ }^{284}$ Unfortunately, the eleventh amendment principles that limit specific relief in general also apply to awards of attorneys' fees. Moreover, any attempt to create an exception for attorneys' fees involves policy considerations which are more appropriately within the realm of legislative rather than judicial competence. While there are persuasive arguments that sovereign immunity does not comport with contemporary norms of justice, it nonetheless has a constitutional stature. Courts may be justified in bending principle to satisfy a compelling need, but the constitutional stature of the problem and the policy implications of its resolution suggest that the provision of legal aid in suits against states be left to legislative resolution, at least where the state manifestly has not acted in bad faith.

The eleventh amendment, however, also places an implied limitation on legislative powers. Until the eleventh amendinent is reinterpreted in some manner, there will be continuing pressures to give the federal government a more flexible role through an expansion of Ex parte Young's illogic. This Comment lias suggested such a reinterpretation-a refined eleventh amendment interpretation that would give the federal government, througl Congress, greater flexibility without judicial abrogation of the eleventh amendment.

284. Brandenburger v. Thompson, 494 F.2d 885, 889 n.5 (9th Cir. 1974). 